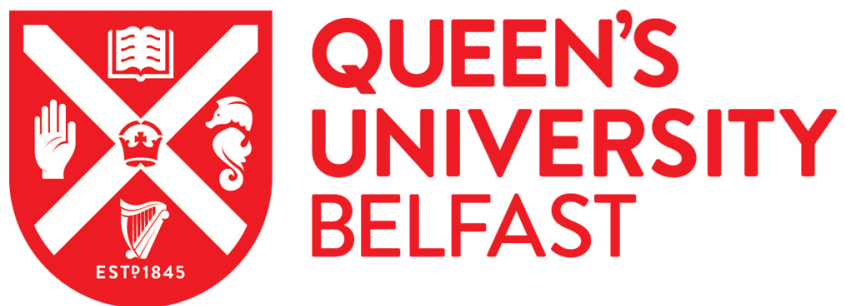

\section{The influence of bedrock hydrogeology on catchment-scale nitrate fate and transport in fractured aquifers}

Orr, A., Nitsche, J., Archbold, M., Deakin, J., Ofterdinger, U., \& Flynn, R. (2016). The influence of bedrock hydrogeology on catchment-scale nitrate fate and transport in fractured aquifers. Science of the Total Environment, 569-570, 1040-1052. https://doi.org/10.1016/j.scitotenv.2016.06.148

Published in:

Science of the Total Environment

Document Version:

Peer reviewed version

Queen's University Belfast - Research Portal:

Link to publication record in Queen's University Belfast Research Portal

\section{Publisher rights}

Copyright 2016 Elsevier

This manuscript is distributed under a Creative Commons Attribution-NonCommercial-NoDerivs License

(https://creativecommons.org/licenses/by-nc-nd/4.0/), which permits distribution and reproduction for non-commercial purposes, provided the author and source are cited.

\section{General rights}

Copyright for the publications made accessible via the Queen's University Belfast Research Portal is retained by the author(s) and / or other copyright owners and it is a condition of accessing these publications that users recognise and abide by the legal requirements associated with these rights.

\section{Take down policy}

The Research Portal is Queen's institutional repository that provides access to Queen's research output. Every effort has been made to ensure that content in the Research Portal does not infringe any person's rights, or applicable UK laws. If you discover content in the Research Portal that you believe breaches copyright or violates any law, please contact openaccess@qub.ac.uk. 

transport in fractured aquifers

3 Alison $\mathrm{Orr}^{1,2^{*}}$, Janka Nitsche ${ }^{3,2^{*}}$, Marie Archbold ${ }^{4,2^{*}}$, Jenny Deakin ${ }^{4,5^{*}}$, Ulrich Ofterdinger ${ }^{2}$, Raymond $4 \quad$ Flynn $^{2}$.

$5 \quad{ }^{1}$ Arup, 50 Ringsend Road, Dublin 4, Ireland

$6 \quad{ }^{2}$ School of Planning, Architecture and Civil Engineering, Queen's University Belfast, UK

$7 \quad{ }^{3}$ RPS, West Pier Business Campus, Dun Laoghaire, Co. Dublin, Ireland

$8 \quad{ }^{4}$ Environmental Protection Agency, Richview, Clonskeagh Road, Dublin 14, Ireland

$9 \quad{ }^{5}$ Department of Civil, Structural and Environmental Engineering, Trinity College Dublin, Ireland

$10 *$ formerly of

12 Abstract

13 Characterising catchment scale biogeochemical processes controlling nitrate fate in groundwater 14 constitutes a fundamental consideration when applying programmes of measures to reduce risks 15 posed by diffuse agricultural pollutants to water quality. Combining hydrochemical analyses with

16 nitrate isotopic data and physical hydrogeological measurements permitted characterisation of 17 biogeochemical processes influencing nitrogen fate and transport in the groundwater in two 18 fractured bedrock aquifers with contrasting hydrogeology but comparable nutrient loads. 19 Hydrochemical and isotopic analyses of groundwater samples collected from moderately fractured, 20 diffusely karstified limestone indicated nitrification controlled dissolved nitrogen fate and delivery to 
1 aquatic receptors. By contrast nitrate concentrations in groundwater were considerably lower in a

2 low transmissivity highly lithified sandstone and pyrite-bearing shale unit with patchy subsoil cover.

3 Geophysical and hydrochemical investigations showed shallower intervals contained hydraulically

4 active fractures where denitrification was reflected through lower nitrogen levels and an isotopic

5 enrichment ratio of 1.7 between $\delta^{15} \mathrm{~N}$ and $\delta^{18} \mathrm{O}$. Study findings highlight the influence of bedrock

6 hydrogeological conditions on aqueous nitrogen mobility. Investigation results demonstrate that

7 bedrock conditions need to be considered when implementing catchment management plans to

8 reduce the impact of agricultural practices on the quality of groundwater and baseflow in receiving

9 rivers.

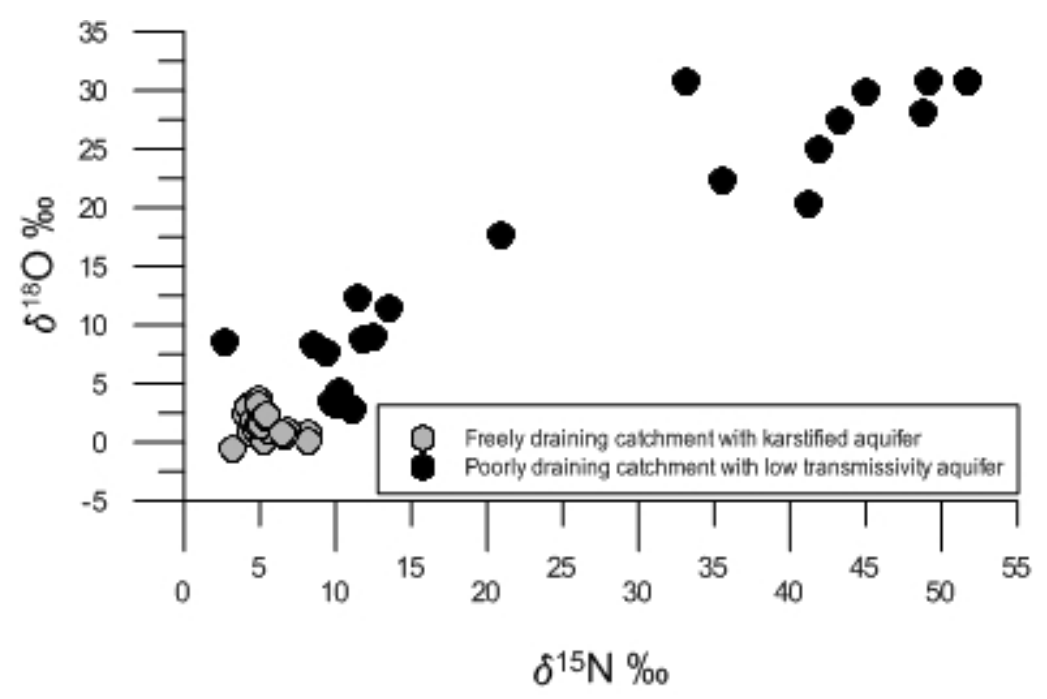

11 Nitrate isotopic signatures in the groundwater of a freely draining catchment underlain by a

12 karstified aquifer and a poorly draining aquifer with a low transmissivity aquifer.

13 Key words

14 Groundwater Nitrate isotopes Nitrification Denitrification 


\section{$1 \quad 1$ Introduction}

2 Excess nitrate $\left(\mathrm{NO}_{3}\right)$ is a global environmental problem which is expected to worsen as a result of

3 factors including the increase in human population, political stress and the development of growing

4 economies (Erisman et al. 2011). Surplus nitrate can reflect loss of soil fertility, while its presence in

5 water can cause human and ecological health problems (McLay et al. 2001). To address the impacts

6 of degraded water quality on human and ecological aquatic health, the European Union (EU)

7 introduced the Water Framework Directive (WFD) (Directive 2000/60/EC) requiring member

8 states to achieve good water quality status in inland surface water and groundwater bodies. Effective

9 implementation of the WFD in areas dominated by agricultural activity, while maintaining economic

10 levels of food production, requires understanding of the fate and transport of diffuse agricultural

11 pollutants, such as nitrate, in the wider environment.

12 Implementing water quality management measures requires an understanding of the factors

13 controlling nitrogen $(\mathrm{N})$ fate and transport. Biogeochemical processes and hydrogeological setting

14 constitute significant factors controlling the fate of nitrogen in groundwater. Previous studies

15 undertaken in various unconsolidated and bedrock aquifers (Burkart \& Koplin 1993), in fractured

16 crystalline and Upper Devonian karstified limestone (Nolan 2001) and catchments underlain by

17 sandstone, limestone and Ordovician sediments (Jahangir et al. 2012), show that aquifers having

18 faster travel times and higher permeability were associated with higher nitrate concentrations. In

19 contrast, Puckett \& Cowdery (2002) found that longer groundwater residence times can allow time

20 for denitrification to occur thus lowering nitrate concentrations in a glacial outwash aquifer.

21 However, a study undertaken in Cretaceous and Jurassic carbonate rocks and detritic sediments

22 (Stigter et al. 2006) and another study in a catchment underlain by Pleistocene deposits (Debernardi

23 et al. 2008) have shown that the relationship between hydrogeological setting and nitrate fate is less 
1 clear cut. Furthermore, even within aquifers geological heterogeneity can influence contaminant

2 transport (Puls \& Paul 1997). Consequently, a better understanding of the biogeochemical processes

3 within different hydrogeological settings is necessary to inform the development of catchment

4 management tools and models. Information relating to processes operating in bedrock is notably

5 scarce. This study investigates the influence of hydrogeological setting on biogeochemical processes,

6 aiming to characterise the dominant processes influencing nitrogen levels in groundwater in two

7 Irish catchments underlain by bedrock aquifers with contrasting (physical and geochemical)

8 hydrogeological properties, but having comparable nutrient loads and thin to no subsoil cover over

9 much of their area. This research considers the spatial heterogeneity of biogeochemical processes

10 within each catchment, both across the catchment and with depth. This has been achieved through

11 monitoring well tracer tests, and analysis of chemical and isotopic signatures of groundwater and

12 surface water. Incorporating the knowledge gained concerning biogeochemical processes into water

13 quality catchment management tools can prove fundamental in reducing the risk posed to

14 groundwater and surface water receptors.

15 Biogeochemical processes affecting nitrate mobility include nitrification, autotrophic and

16 heterotrophic denitrification, ammonification, anammox and dissimilatory nitrate reduction to

17 ammonium (DNRA) (Rivett et al. 2008), and are summarised by Equations 1 to 8 in Table 1.

18 Ammonification is the process by which ammonium is produced from organic N. This process

19 occurs more rapidly under aerobic conditions, but can also occur within anaerobic conditions

20 (Reddy and Patrick 1984). Nitrification is the microbial oxidation of ammonium to nitrate

21 (Equations 1 and 2), which is considered a critical nutrient in controlling aquatic ecosystem

22 productivity (and eutrophication). By contrast, denitrification has been identified as the most

23 important biogeochemical process in the removal of nitrate from groundwater (Rivett et al. 2008;

24 Korom 1992; Burgin \& Hamilton 2007). The emphasis on denitrification over other nitrate removal 
1 processes arises due to the widespread occurrence of denitrifying bacteria, perceived high nitrate

2 removal capacity of denitrification and the relatively limited capacity for alternative processes to

3 remove nitrate (Rivett et al. 2008; Burgin \& Hamilton 2007). Denitrification rates are limited by

4 oxygen concentrations and require the presence of $\mathrm{N}$ oxides $\left(\mathrm{NO}_{3}, \mathrm{NO}_{2}, \mathrm{NO}\right.$ and $\left.\mathrm{N}_{2} \mathrm{O}\right)$ and

5 electron donors (e.g. dissolved organic carbon or pyrite) as outlined in Equations 3, 4 and 5. Other

6 processes influencing aqueous nitrogen's mobility in the wider environment include anammox

7 (anaerobic ammonium oxidation), which is the oxidation of ammonium and reduction of nitrite to

8 produce nitrogen gas $\left(\mathrm{N}_{2}\right)$, as outlined in Equations 6 and 7. DNRA has been identified in

9 groundwater using hydrochemical investigative tools (Smith et al. 1991; Jahangir et al. 2012) and is

10 outlined in Equation 8 (Giblin et al. 2013). The presence of anaerobic conditions and a negative

11 correlation between nitrate and ammonium in groundwater has been linked to the occurrence of

12 DNRA (Jahangir et al. 2012).

13 Table 1 Chemical equations for biogeochemical processes affecting nitrate fate

\begin{tabular}{|l|l|l|l|}
\hline Nitrification & $\begin{array}{l}\mathrm{NH}_{4}{ }^{+}+2 \mathrm{O}_{2} \rightarrow \mathrm{NO}_{2}{ }^{-}+\mathrm{H}_{2} \mathrm{O}+\mathrm{H}_{2} \mathrm{O}+\mathrm{H}^{+} \\
\mathrm{NO}_{2}{ }^{-}+0.5 \mathrm{O}_{2} \rightarrow \mathrm{NO}_{3}^{-}\end{array}$ & $\begin{array}{l}\text { Equation 1 } \\
\text { Equation 2 }\end{array}$ & $\begin{array}{l}\text { (Willey et al. 2011) } \\
\text { (Willey et al. 2011) }\end{array}$ \\
\hline Denitrification & $\begin{array}{l}4 \mathrm{CH}_{2} \mathrm{O}+4 \mathrm{NO}_{3}-2 \mathrm{~N}_{2}+4 \mathrm{HCO}_{3}+\mathrm{CO}_{2}+2 \mathrm{H}_{2} \mathrm{O} \\
5 \mathrm{FeS}_{2}+14 \mathrm{NO}_{3}+4 \mathrm{H}^{+} \rightarrow 5 \mathrm{Fe}^{2+}+7 \mathrm{~N}_{2}+10 \mathrm{SO}_{4}{ }^{2}+2 \mathrm{H}_{2} \mathrm{O} \\
\mathrm{NO}_{3}{ }^{-}+5 \mathrm{Fe}^{2+}+7 \mathrm{H}_{2} \mathrm{O} \rightarrow 0.5 \mathrm{~N}_{2}+5 \mathrm{FeOOH}+9 \mathrm{H}^{+}\end{array}$ & $\begin{array}{l}\text { Equation 3 } \\
\text { Equation 4 } \\
\text { Equation 5 }\end{array}$ & $\begin{array}{l}\text { (Jørgensena et al. } \\
\text { (Te04) } \\
\text { (Tesoriero et al. 2000) } \\
\text { (Kölle et al. 1990; } \\
\text { Ottley et al. 1997) }\end{array}$ \\
\hline Anammox & $\begin{array}{l}\mathrm{NH}_{4}{ }^{+}+\mathrm{NO}_{2}{ }^{-} \rightarrow \mathrm{N}_{2}+2 \mathrm{H}_{2} \mathrm{O} \\
3 \mathrm{NO}_{3}{ }^{-}+5 \mathrm{NH}_{4}{ }^{+} \rightarrow 4 \mathrm{~N}_{2}+9 \mathrm{H}_{2} \mathrm{O}+2 \mathrm{H}^{+}\end{array}$ & $\begin{array}{l}\text { Equation 6 } \\
\text { Equation 7 }\end{array}$ & $\begin{array}{l}\text { (Mulder et al. 1995) } \\
\text { (Kuenen 2008) }\end{array}$ \\
\hline DNRA & $2 \mathrm{CH}_{2} \mathrm{O}+\mathrm{NO}_{3}{ }^{-}+\mathrm{H}_{2} \mathrm{O} \rightarrow \mathrm{NH}_{4}{ }^{+}+2 \mathrm{HCO}_{3}{ }^{-}$ & Equation 8 & (Giblin et al. 2013) \\
\hline
\end{tabular}

14

15 The range of processes influencing the fate of aqueous nitrogen, along with the products generated,

16 limit confident identification of the specific processes involved based on the results of 
1 hydrochemical analyses alone. Additional methods, particularly when combined with appropriate

2 hydrogeological conceptual models, can assist in better constraining the range of significant

3 processes. Isotopic analyses of $\delta^{15} \mathrm{~N}$ to $\delta^{18} \mathrm{O}$ levels in nitrate provide a useful tool for distinguishing

4 nitrate sources and attenuation processes. The identification of nitrate sources using nitrate isotopes

5 proves particularly useful in well oxygenated hydrogeological environments where minimal

6 biogeochemical cycling of $\mathrm{N}$ occurs, allowing the source signal to persist (Savard et al. 2010). On the

7 other hand, fractionation caused by other biogeochemical processes can alter the isotopic signatures.

8 Previous groundwater studies have attributed an enrichment of $\delta^{15} \mathrm{~N}$ to $\delta^{18} \mathrm{O}$ by a factor of between

$9 \quad 1.3$ and 2.1 to denitrification (Böttcher et al. 1990; Aravena \& Robertson 1998; Fukada et al. 2003).

10 Fractionation processes influencing ammonia prior to its ammonification to ammonium and

11 subsequent nitrification to nitrate can have an impact on the nitrate isotopic signature. Volatilisation

12 of ammonia results in isotopic enrichment of the residual $\mathrm{NH}_{4}$ as lighter $\delta^{14} \mathrm{~N}$ is released in the $\mathrm{NH}_{3}$

13 gas (Mayer 2005). This enrichment of the residual $\mathrm{N}$ can be $>20 \%$ (Kendall 1998) and can generate

14 an enriched $\mathrm{N}$ signature in the resulting $\mathrm{NO}_{3}$.

15 Previous studies have used nitrate isotopes to investigate sources and fate of nitrate from field scale

16 to catchment scale (Hiscock et al. 2011; Heffernan et al. 2012; Baily et al. 2011). However, studies

17 have focused on processes operating in soils and subsoils, particularly coarser grained materials

18 (Böttcher et al. 1990; Smith et al. 1991; Baily et al. 2011; Minet et al. 2012). Investigations into the

19 fate and transport of nitrate in competent fractured rock units are far less common, particularly in

20 those units with little to no matrix porosity, with even fewer studies examining the fate of nitrate in

21 bedrock and the variation in attenuation with depth (Fukada et al. 2004). Furthermore many studies

22 focus on an individual study catchment and fail to consider differences between catchments with

23 contrasting bedrock. 
1 Bedrock conditions in the areas considered by this study are representative of conditions

2 encountered over much of the island of Ireland in that they consist of fractured bedrock with

3 negligible primary porosity, overlain by variable thicknesses of subsoil, including large areas where

4 subsoil is less than three metres thick. The bedrock in one catchment is a productive moderately

5 karstified Dinantian (Lr. Carboniferous/Mississippian) limestone lacking a significant conduit

6 network, while that in the other is a highly lithified Silurian sandstone (greywacke) containing beds

7 of pyrite-bearing shale. Previous studies of contaminant transport in catchments underlain by

8 limestone have focused on processes operating in larger conduit networks (Panno et al. 2001;

9 Heffernan et al. 2012), or systems where denitrification is only significant where the aquifer is

10 confined and oxygen depleted (Rivett et al. 2007; Hiscock et al. 2011). Processes operating in less

11 fractured unconfined limestone units remain less studied. Similarly, nitrate fate and transport has

12 been rarely studied in poorly productive (Low Productivity) bedrock units such as Silurian

13 greywacke. Moreover, previous studies of groundwater quality have noted that hydrochemical

14 stratification may occur with depth (Fukada et al. 2004; Böttcher et al. 1990).

\section{$15 \quad 2$ Materials and Methods}

\section{$16 \quad 2.1$ Site description}

\section{$17 \quad 2.1 .1$ Nuenna}

18 The Nuenna Catchment in Co. Kilkenny, Ireland covers an area of $35 \mathrm{~km}^{2}$ (Figure 1 and Figure 2).

19 Annual rainfall in the catchment is $985 \mathrm{~mm}$ and evapotranspiration is $485 \mathrm{~mm}$ (O'Brien et al. 2013).

20 The catchment experiences a cool maritime climate with year-round rainfall and temperatures that

21 rarely drop below freezing. Effective rainfall is greatest in the winter period from late October to

22 early March when evapotranspiration is at a minimum. Climate conditions during the study period

23 were typical for the area investigated. 
1 Teagasc soil and subsoil maps note well drained brown earths and grey brown podzolic soils overlie

2 subsoils consisting of moderately permeable limestone tills, present on the valley slopes, and an

3 alluvial gravel unit (GSI 2012). The alluvial gravel is $8 \mathrm{~m}$ thick at the NU2 monitoring wells location

4 (Figure 1 and Figure 2) and occurs in the vicinity of the river from the mid catchment to the

5 catchment outlet.

6 The groundwater vulnerability maps derived by the Geological Survey of Ireland (GSI) show that

7 approximately $65 \%$ of the aquifer is classified as having Extreme vulnerability, with less than $3 \mathrm{~m}$

8 subsoil cover, or X-Extreme vulnerability, with less than $1 \mathrm{~m}$ subsoil cover and where rock is at or

9 near surface, or karst is present (Figure 1). The remaining $35 \%$ of the aquifer is classified as high

10 vulnerability, with a subsoil thickness of up to $10 \mathrm{~m}$, occurring predominantly in lower lying areas,

11 including groundwater discharge zones. The Nuenna Catchment is underlain by pure bedded

12 Dinantian (Lower Carboniferous or Mississippian) limestone. The groundwater vulnerability maps

13 suggest that over the majority of the Nuenna Catchment diffuse recharge passes through variable

14 thickness of soil and subsoil before entering the bedrock.

15 Focused recharge can occur in karst features, such as swallow holes (Figure 2). During diffuse

16 infiltration, recharge flows through the transition zone prior to entering the diffuse karst network.

17 This occurs particularly in areas of higher elevation, approaching the catchment divide, where the

18 limestone is overlain by poorly-productive Namurian (Lr. Pennsylvanian) sandstones and pyrite-

19 bearing shales (GSI 2012). Further groundwater in the diffuse karst network drains into the conduits

20 which ultimately discharge to the Nuenna River though a series of springs and, more diffusely,

21 through the alluvial gravel unit in the lower reaches of the catchment. The hydrogeological

22 properties of the rock matrix play a critical role influencing the rate of delivery to the conduit system

23 (Orr 2014). 
1 Transmissivity values, determined from seven pumping tests and nine spring recession events, range

2 from $0.3 \mathrm{~m}^{2} /$ day, within the bedrock matrix, to up to $750 \mathrm{~m}^{2} /$ day, within the conduit discharge

3 zones, reflecting high levels of hydraulic conductivity heterogeneity (Cawley 1990; Orr 2014).

4 Although no hydrogeological data exists for the Namurian shale unit in the Nuenna Catchment,

5 comparison with other poorly productive Irish aquifers suggests hydrogeological processes in the

6 area are dominated by surface and near-surface runoff (Archbold et al. 2016). This has been

7 corroborated by field observations during hydrologically energetic periods.

8 Two monitoring well clusters, NU1 and NU2 (Figure 1 and Figure 2), were used for water level and

9 water quality monitoring in the Nuenna catchment. The monitoring wells' open sections lie within

10 (a) the subsoil, (b) the interval of elevated physical weathering occurring in the vicinity of the

11 bedrock/overburden interface (transition zone), which may be locally absent, (c) the shallower

12 bedrock, and (d) the deeper limestone bedrock (Table 2). The Nuenna River acts as the principal

13 surface water body in the catchment. It has a baseflow index of $>0.87$ reflecting the importance of

14 groundwater for stabilising flow (O’Brien et al. 2013). Baseflow at the catchment outlet was

15 determined as being between approximately 0.2 and $0.4 \mathrm{~m}^{3} / \mathrm{s}$ (Orr 2014).

16 Landuse across the Nuenna Catchment consists of $>70 \%$ pasture, $14 \%$ arable and $8 \%$ woodland,

17 with farmyards, rural settlement and unspecified landuse occupying the remaining land (McAleer

18 2011). Catchment wide average diffuse $\mathrm{N}$ loadings were estimated to be $152 \mathrm{~kg} \mathrm{~N} / \mathrm{ha} / \mathrm{yr}$ from

19 inorganic fertiliser (52\%) and $140 \mathrm{~kg} \mathrm{~N} / \mathrm{ha} / \mathrm{yr}$ from livestock manure (48\%) (Orr 2014). A land use

20 survey of the catchment indicated greater loading of inorganic fertiliser occurred on the valley floor

21 associated with arable land use, while organic $\mathrm{N}$ loading occurred in the more elevated southern and

22 northern parts of the catchment as a result of higher livestock density (McAleer 2011). 


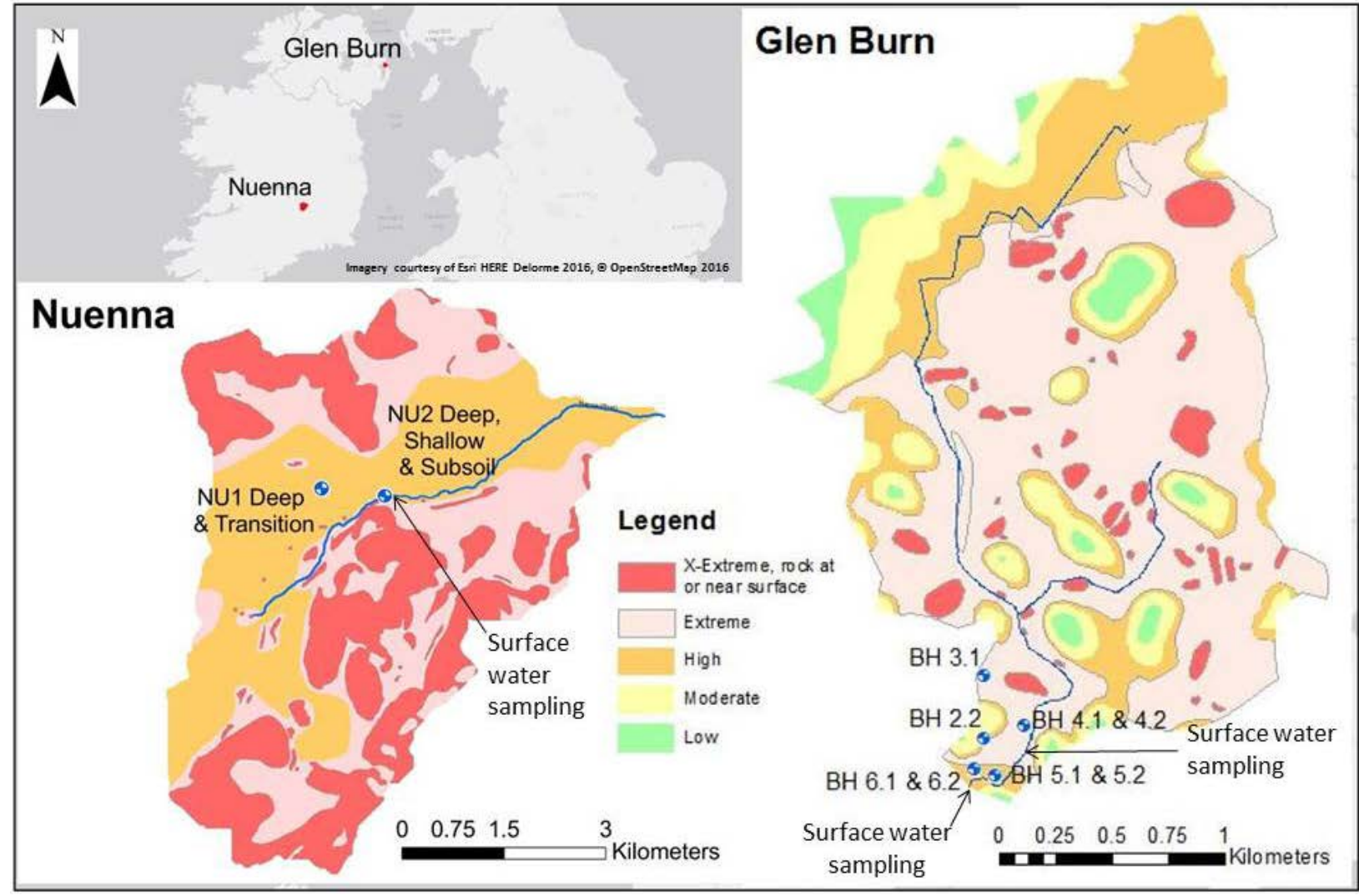

Figure 1 Catchment locations, groundwater vulnerability (GSI 2012 and Meredith 2010) and monitoring well layout in the Glen Burn and Nuenna catchments
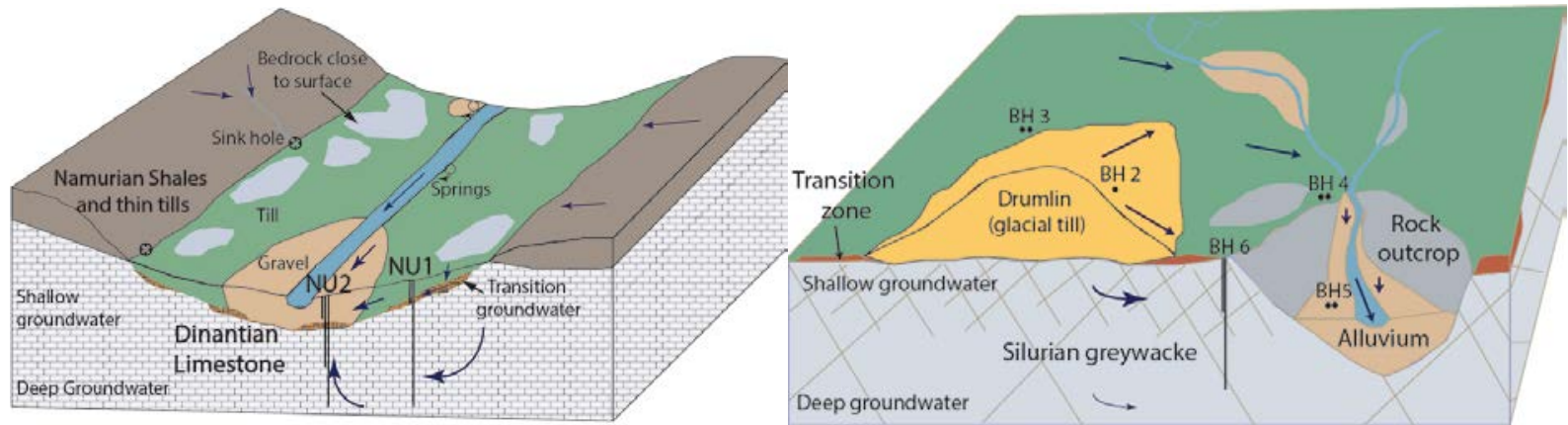

Figure 2 Simplified conceptual hydrogeological models of the Nuenna (left) and Glen Burn (right) catchments. Arrows show flow direction and arrow weight reflects the flow volume. Not to scale.

\subsubsection{Glen Burn}

9 The Glen Burn Catchment is located in Co. Down, Northern Ireland and covers an area of $5 \mathrm{~km}^{2}$

10 (Figure 1 and Figure 2). Annual rainfall in the catchment is $843 \mathrm{~mm}$ and evapotranspiration is 460

$11 \mathrm{~mm}$ (O’Brien et al. 2013). The catchment experiences a cool maritime climate similar to the Nuenna 
1 with temperatures rarely dropping below freezing. Climate conditions during the study period were

2 typical for the study area investigated.

3 Where they occur, soils consist of a thin coverage of low permeability rankers, surface water gleys

4 and groundwater gleys. Localised mounds of glacial till (drumlins) dominate higher elevations, while

5 very thin glacial till subsoils (less than $1 \mathrm{~m}$ thick) and rock outcrops occur in areas of lower elevation.

6 A thin covering of alluvium occurs locally in the vicinity of the river. Figure 1 shows the majority of

7 the catchment is classified as extreme vulnerability due to the thin subsoil cover, while areas overlain

8 by drumlins are classified as having moderate to low vulnerability (Meredith 2010).

9 The Glen Burn Catchment is underlain by greywacke sandstone and shale belonging to the Silurian

10 Gala Group. Transmissivity values, determined from pumping tests, range from $0.18 \mathrm{~m}^{2} /$ day in the

11 shallow fissured bedrock to $0.07 \mathrm{~m}^{2} /$ day in deeper more composite bedrock (Comte et al. 2012).

12 The aquifer is classified as "Limited Productivity with Fracture Flow" by the Geological Survey of

13 Northern Ireland (McConvey 2012). Such aquifers typically have low yields, limited regional flow,

14 shallow local flow paths and few transmissivity values $>500 \mathrm{~m}^{2} /$ day, some transmissivity values

$15>50 \mathrm{~m}^{2} /$ day and most transmissivity values $<50 \mathrm{~m}^{2} /$ day (McConvey 2012; GSI 2016). Groundwater

16 flow occurs predominantly through fractures, with negligible matrix flow. The transmissivity data

17 suggest that near surface and shallow groundwater pathways act as the dominant hydrological routes

18 for delivering groundwater to the Glen Burn River. Four monitoring well clusters, located in the

19 lower Glen Burn catchment, occur between $30 \mathrm{~m}$ and $350 \mathrm{~m}$ from the river, and have monitoring

20 points screened against the shallow bedrock and deep bedrock (Figure 1, Figure 1 and Table 2). A

21 fifth cluster is located in the alluvium. The river has a low baseflow index (BFI) of $<0.13$ (O’Brien et

22 al. 2013). Baseflow at the catchment outlet is between approximately 0.002 and $0.008 \mathrm{~m}^{3} / \mathrm{s}$ (Orr

23 2014). 
1 Landuse across the catchment consists of $82 \%$ pasture, $10 \%$ arable and $5 \%$ woodland, with

2 farmyards and rural settlement occupying the remaining land (Meredith 2010). Catchment-wide

3 average $\mathrm{N}$ loadings were estimated to be $125 \mathrm{~kg} \mathrm{~N} / \mathrm{ha} / \mathrm{yr}$ from inorganic fertiliser (37\%) and $213 \mathrm{~kg}$

$4 \mathrm{~N} / \mathrm{ha} / \mathrm{yr}$ from livestock manure (63\%).

\section{$5 \quad 2.2$ Methods}

6 Both physical and chemical methods were carried out in order to characterise the dominant

7 hydrogeological processes influencing nitrogen levels in groundwater within the two catchments and

8 to consider the spatial heterogeneity on biogeochemical processes with depth in both catchments.

\section{$9 \quad$ 2.2.1 Artificial tracer tests}

10 Conventional methods of identifying hydraulically active fractures in bedrock monitoring wells

11 require significant levels of active or induced flow. The threshold levels for these methods often lies

12 below the rates flowing through fractures in poorly productive bedrock units. Artificial tracer testing

13 provides an alternative means of investigating flow regimes in these low-flowing systems. In the

14 current study uranine (sodium fluorescein) tracer tests were carried out to identify hydraulically

15 active fractures in bedrock. A flexible pipe connected to a $50 \mathrm{~m}$ long tube was lowered to the base of

16 the monitoring well and the uranine tracer was then poured into the tube to displace monitoring well

17 water as the tube was raised to the surface at an even rate. Following tracer injection, the tubing was

18 lowered and raised to homogenise the tracer within the monitoring well.

19 Following mixing, a portable GGUN fluorometer FL30 (Aliba, Neuchâtel) was lowered slowly into

20 the monitoring well. This took triplicate measurements of tracer concentration at $0.5 \mathrm{~m}$ intervals to a

21 maximum depth of $60 \mathrm{~m}$. The process was repeated three to four times, up to 6 days after the

22 injection, or until the uranine concentrations had fallen below the fluorometer's detection limit. 
1 Modelling the results of observed tracer concentrations permitted hydraulically active intervals to be

2 identified and reconciled with the results of geophysical monitoring well logging (Nitsche 2014).

\section{$3 \quad$ 2.2.2 Water Chemistry Sampling}

4 Groundwater samples in the Nuenna catchment were collected during 20 groundwater sampling 5 rounds between July 2010 and November 2012, while eleven groundwater sampling rounds were

6 carried out in the Glen Burn catchment between February 2011 and November 2012. The sampling

7 strategy for both catchments followed the British Standard BS ISO 5667-11:2009 and BS 6068-

8 6.11:2009 protocols. Whale Mini-Purgers were used to extract groundwater from the monitoring

9 wells with lower yields (all Glen Burn monitoring wells, NU1 Transition and NU2 Shallow), Whale

10 Mega-Purgers were used in higher yielding monitoring wells (NU2 Deep and Subsoil); a Grundfos

11 MP1 pump was used in NU1 Deep as the depth to groundwater exceeded the pumping head of the

12 Whale Purgers. Whole monitoring well sampling regimes can fail to account for vertical flows

13 (McMillan et al. 2014) and changes in biogeochemical processes with depth. Therefore, depth

14 specific samples were taken on one additional sampling round in each monitoring well using a

15 pneumatic double-packer system and Solinst Integra Bladder Low Flow Pump from intervals

16 identified as hydraulically active by artificial tracer testing to investigate potential mixing of waters

17 with contrasting chemistries.

18 Monitoring well construction details for both catchments are summarised in Table 2. During

19 sampling, the wells were pumped until the groundwater's field hydrochemical parameters (dissolved

20 oxygen (DO), $\mathrm{pH}$, electrical conductivity (EC), oxidation reduction potential (ORP) and

21 temperature), measured using a TPS 90FL-MV water quality meter and flow through cell, stabilised.

22 Water chemistry samples were collected in HDPE plastic bottles and stored within ice during 23 transport to the laboratory following the protocol set out by the British Standard BS EN ISO 5667- 
Table 2 Monitoring well construction details in the Nuenna and Glen Burn catchments

\begin{tabular}{|c|c|c|c|c|c|c|}
\hline & $\begin{array}{l}\text { Monitoring } \\
\text { well ID }\end{array}$ & $\begin{array}{l}\text { Depth of } \\
\text { monitor- } \\
\text { ing well } \\
\text { (m) }\end{array}$ & GW body & $\begin{array}{l}\text { Monitoring well } \\
\text { type }\end{array}$ & $\begin{array}{l}\text { Depth of } \\
\text { open } \\
\text { Section/ } \\
\text { screened } \\
\text { interval (m) }\end{array}$ & $\begin{array}{l}\text { Approx. } \\
\text { distance } \\
\text { from river } \\
\text { (m) }\end{array}$ \\
\hline \multirow{5}{*}{ 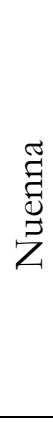 } & NU1 Deep & 74.4 & Deep & $152 \mathrm{~mm}$ open hole & 36 to 74.4 & 620 \\
\hline & $\begin{array}{l}\text { NU1 } \\
\text { Transition }\end{array}$ & 7.3 & Transition & $\begin{array}{l}152 \mathrm{~mm} \text { PVC screen } \\
\text { with } 2 \mathrm{~mm} \text { slots }\end{array}$ & 3.3 to 7.16 & 625 \\
\hline & NU2 Deep & 79.5 & Deep & $152 \mathrm{~mm}$ open hole & 33.8 to 79.5 & 20 \\
\hline & NU2 Shallow & 27.4 & Shallow & $\begin{array}{l}152 \mathrm{~mm} \text { PVC screen } \\
\text { with } 2 \mathrm{~mm} \text { slots }\end{array}$ & 11.5 to 26.32 & 22 \\
\hline & NU2 Subsoil & 9.3 & Subsoil & $\begin{array}{l}152 \mathrm{~mm} \text { PVC screen } \\
\text { with } 2 \mathrm{~mm} \text { slots }\end{array}$ & 5.5 to 8.38 & 24 \\
\hline \multirow{8}{*}{ 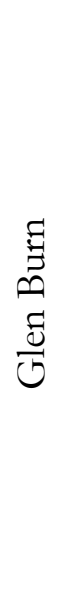 } & 2.2 & 10.2 & Shallow & $152 \mathrm{~mm}$ open hole & 4.2 to 10.2 & 175 \\
\hline & 3.1 & 19.58 & Deep & $50 \mathrm{~mm}$ PVC screen & 15 to 21 & 350 \\
\hline & 4.1 & 34.33 & $\begin{array}{l}\text { Shallow and } \\
\text { deep }\end{array}$ & $152 \mathrm{~mm}$ open hole & 3.0 to 31.8 & 50 \\
\hline & 4.2 & 5.7 & Shallow & $152 \mathrm{~mm}$ open hole & 1.4 to 5.7 & 50 \\
\hline & 5.1 & 3.5 & Alluvium & $152 \mathrm{~mm}$ open hole & 3.5 to 7.5 & 30 \\
\hline & 5.2 & 2.5 & Alluvium & $50 \mathrm{~mm}$ PVC screen & 1.5 to 2.5 & 30 \\
\hline & 6.1 & 60 & $\begin{array}{l}\text { Shallow and } \\
\text { deep }\end{array}$ & $152 \mathrm{~mm}$ open hole & 8.7 to 60 & 40 \\
\hline & 6.2 & 9 & Shallow & $152 \mathrm{~mm}$ open hole & 4.9 to 9 & 40 \\
\hline
\end{tabular}

\section{$4 \quad$ 2.2.3 Laboratory chemical analyses}

5 Ion chromatography analyses of target anions $\left(\mathrm{NO}_{2}, \mathrm{NO}_{3}, \mathrm{NH}_{4}, \mathrm{SO}_{4}, \mathrm{Cl}\right)$ were carried out within 48

6 hours of collection using a Dionex ${ }^{\circledR}$ DX-500 and ICS-2000. Prior to analysis the samples were

7 filtered through $0.45 \mu \mathrm{m}$ sterile Millex® MCE membrane filters. Alkalinity was measured using a

8 Hach ${ }^{\circledR}$ digital titrator model 16900. Ferrous iron $\left(\mathrm{Fe}^{2+}\right)$ analysis was carried out using the Hach

$9 \quad$ Lange ${ }^{\circledR}$ DR 2800 Spectrophotometer. Samples collected for dissolved organic carbon analysis were 
1 filtered through $0.45 \mu \mathrm{m}$ sterile Millex MCE membrane filters and then analysed using a UV

2 promoted persulfate oxidation method on a TOC analyser (Sievers® ${ }^{\circledR}$ 5310C Laboratory TOC

3 Analyzer).

4 Groundwater samples used for nitrate isotopic analyses were collected during six of the sampling

5 rounds in both study catchments including the packer testing. Samples were filtered on site directly

6 into HDPE containers before freezing. Isotopic analysis for $\delta^{15} \mathrm{~N}-\mathrm{NO}_{3}$ and $\delta^{18} \mathrm{O}-\mathrm{NO}_{3}$ was carried

7 out at the Stable Isotope facility in UC Davis, California using the bacterial denitrification assay

8 method (Casciotti et al. 2002).

\section{$9 \quad 3 \quad$ Results and Discussion}

\section{$10 \quad 3.1$ The Nuenna Catchment}

11 Water level monitoring reveals that shallow bedrock (approximately $<25 \mathrm{~m}$ BGL) in the Nuenna

12 catchment is generally unsaturated, although in the areas of lower elevation, close to the Nuenna

13 River, it may be saturated. Slower flow in the shallow bedrock at NU2 Shallow is reflected by the

14 lower tracer dilution rates observed over a similar time frame in NU2 Shallow ( $>80 \%$ over 123

15 hours), compared to NU2 Deep (below detection limit after 141 hours). The levels of uranine

16 dilution observed at NU2 Shallow reflect limited levels of groundwater throughflow. However,

17 slightly lower tracer concentrations observed with depth suggest upward flowing groundwater,

18 consistent with upwelling discharge close to the river. Therefore, although the transmissivity values

19 in the diffuse karst of the shallow and deep bedrock units at NU2 lie within the same order of

20 magnitude, between $0.3 \mathrm{~m}^{2} /$ day and $1.5 \mathrm{~m}^{2} /$ day (Orr 2014), flow through the shallower bedrock

21 unit may be slower than in the deep bedrock, reflecting the hydrogeological heterogeneity of the

22 diffuse karst bedrock. 
1 Results of tracer tests completed at NU1 showed a significant dilution in uranine concentration,

2 suggesting inflow at approximately $35.5 \mathrm{~m}$ below ground level (bgl) in NU1 Deep and indicating the

3 presence of a hyraulically active fracture(s). This interval corresponds with a fracture set identified in

4 the geophysical caliper and HiRAT logging (Moran \& Crean 2010). Moreover, tracer test results

5 suggest that additional hydraulically active fracture sets may be present at approximately $44-45 \mathrm{~m}$

6 below ground level (bgl), which also corroborate findings of caliper and high resolution acoustic

7 televiewer (HiRAT) geophysical logs. However as dilution is less significant, it is likely that this

8 fracture set was less hydraulically active than the set at $35.5 \mathrm{~m}$ at the time of testing.

9 The responses of uranine tracer test results highlights the heterogeneity of fracture flow within the

10 diffuse fracture network of the karst bedrock and suggests a component of vertical flow within the

11 monitoring well in the form of upwelling close to the river. Such vertical flow may generate

12 sampling bias (McMillan et al. 2014) and therefore point to the need for depth specific packer

13 testing. The hydraulic conductivity of the bedrock matrix at NU2 Deep and Shallow and point to

14 hydraulically active fractures which act as the dominant transport groundwater pathway; processes

15 operating within these fractures therefore are likely to dominate groundwater nitrate concentrations..

\section{$16 \quad$ 3.1.1 Hydrochemistry}

17 Hydrochemical conditions in the two monitoring well clusters in the Nuenna catchment vary both

18 spatially (with depth and laterally) and temporally. Lower median nitrate and DO concentrations are

19 evident in the shallower transition zone groundwater in comparison to the deep groundwater (Table

203 and Figure 3). Occasional relatively low concentrations of nitrate $(<9 \mathrm{mg} / \mathrm{l})$ are likely to be as a

21 result of intermittent attenuating reactions, rather than dilution, as they did not coincide with lower

22 chloride concentrations and the $\mathrm{NO}_{3} / \mathrm{Cl}$ ratio was $<0.7$. The non-reactive nature of chloride (Davis

23 et al. 1998) provides a basis for evaluating the transformation of reactive species. Variations in 
1 absolute concentrations can confuse evaluation due to differential loading. The use of ratios of

2 reactive species to chloride provides a means of reducing this influence. On the occasion when the

3 lowest recorded concentrations of nitrate $(5 \mathrm{mg} / \mathrm{l})$ were detected, anaerobic conditions were noted

4 through the absence of DO $(<1 \mathrm{mg} / \mathrm{l})$. This coincided with elevated $\mathrm{HCO}_{3}$ concentrations $(512$

$5 \mathrm{mg} / \mathrm{l}$ ) suggesting heterotrophic denitrification (Equation 3, Jørgensena et al., 2004). Moreover,

6 analysis of field hydrochemical monitoring data demonstrates that redox conditions in the transition

7 zone groundwater fluctuate. This is further evidence that the transition zone can occasionally

8 provide suitable conditions for denitrification to occur. However, as these conditions are sporadic,

9 the potential for nitrate removal in the transition groundwater has very limited capacity to affect

10 nitrate concentrations at a catchment scale.

11 Overall, higher median nitrate concentrations were observed in the deep groundwater, compared to

12 the samples collected from monitoring wells screened in the transition zone (Table 3 and Figure 3).

13 This suggests that the recharge containing higher concentrations of nitrate bypassed upper layers

14 and entered the deep groundwater body through localised (non-uniform) entry points such as

15 swallow holes or areas where the subsoil is thin or absent (Table 3). Tracer testing carried out in

16 swallow holes and springs within the catchment has demonstrated that focused recharge can enter

17 the limestone aquifer in areas of higher elevation close to the contact with the overlying sandstone

18 and shale units (Hogan 2011); these correspond to areas of higher organic fertiliser application.

19 In the case of the deep groundwater samples there was a contrast in the median nitrate

20 concentrations between NU1 Deep and NU2 Deep (Table 3 and Figure 3). Slightly higher nitrate

21 concentrations observed in NU1 Deep compared to NU2 Deep are suspected to reflect some

22 heterogeneity in nitrate loading as well as dilution with less impacted water containing lower 
1 concentrations of $\mathrm{N}$ closer to the river. The significance of dilution is further highlighted by similar

$2 \quad \mathrm{NO}_{3} / \mathrm{Cl}$ ratios (Figure 3).

3 Hydrochemical analyses revealed the lowest median nitrate, DO and ORP values were detected in

4 the shallow groundwater pathway at NU2 Shallow (Table 2). The anaerobic conditions associated

5 with NU2 Shallow create a distinctly different hydrochemical signature compared to the deeper

6 units. DO and ORP conditions observed compare to those suggested in literature as being suitable

7 for denitrification (Jahangir et al. 2012; Thomasson et al. 1991). However, DOC concentrations in

8 the shallow groundwater at NU2 Shallow are relatively low (Table 3) compared to the other

9 monitoring well locations. DOC concentrations at NU2 Shallow are also generally below the

10 suggested threshold for denitrification of $2 \mathrm{mg} / 1$ DOC (Thomasson et al. 1991), with the exception

11 of a single spike of $17.3 \mathrm{mg} / \mathrm{l}$ DOC. A septic tank connected to a restaurant/pub discharges

12 hydroxide based cleaning agents into the groundwater upgradient of the NU2 monitoring well

13 cluster. The hydroxide results in a higher $\mathrm{pH}$ and low $\mathrm{HCO}_{3}$ concentrations at NU2 Shallow

14 monitoring well compared to the other monitoring wells. Therefore, the relationship between nitrate

15 and $\mathrm{HCO}_{3}$ cannot be considered useful regarding heterotrophic denitrification at NU2 Shallow.

16 However, on the basis of the generally low DOC levels it is unlikely that heterotrophic

17 denitrification occurred within the shallow groundwater. Autotrophic denitrification is also unlikely

18 in the shallow groundwater as $\mathrm{Fe}^{2+}$ concentrations were below the detection limit $(10 \mu \mathrm{g} / \mathrm{l})$.

19 Hydrochemical analyses for samples collected at the NU2 cluster suggest that DNRA (see Equation

20 8) might account for nitrate removal in the shallow groundwater as median ammonium

21 concentrations are relatively high. DNRA is favoured when nitrate availability is the principal

22 limiting factor, while denitrification is favoured when carbon availability is limiting (Korom 1992).

23 However, as both nitrate and DOC concentrations are relatively low in the shallow groundwater it is 
1 unclear which may be limiting. It is also unclear how much the nitrification or denitrification is

2 affected by the high $\mathrm{pH}$ in the shallow groundwater. Denitrification can operate at a $\mathrm{pH}$ of up to

310.2 (Thomasson et al. 1991) with the optimum pH for nitrification lying between 7 and 8 (Tarre \&

4 Green 2004). Additionally, anammox may be occurring as it can take place where nitrate and

5 ammonium coexist and carbon is limited (Burgin \& Hamilton 2007). However, it is most likely that

6 elevated $\mathrm{NH}_{4}$ concentrations is entering the shallow groundwater from the septic tank up-gradient

7 of the NU2 cluster, and due to low DO conditions nitrification is inhibited, allowing the $\mathrm{NH}_{4}$ to

8 persist.

9 The similar median nitrate concentrations observed in the alluvial gravel subsoil groundwater and

10 the river water samples are consistent with a strong hydraulic connection between the river and the

11 alluvium. This is supported by in-stream artificial tracer testing which suggested considerable

12 exchange of water between the alluvial gravel aquifer and the river (Hogan 2011). The alluvial gravel

13 aquifer extends from the middle of the catchment to the catchment outlet along the valley floor

14 adjacent to the river. The similar nitrate concentrations in the river and the alluvial deposits suggest

15 that the alluvium may act as a temporary reservoir for nitrate and has limited capacity for nitrate

16 removal.

17 The results of water quality analyses suggest that very localised processes have a strong influence on

18 the water quality in the NU2 Shallow monitoring well. However, it is unlikely that these conditions

19 are significant throughout the catchment as the nitrate and major ion concentrations of the water

20 within the river at baseflow conditions resemble those observed in the deeper monitoring wells,

21 such as NU1 Deep and NU2 Deep. This is further corroborated by the results of isotopic analyses

22 (below) and highlights the dominance of groundwater delivered via deeper pathways which controls

23 river baseflow and overprints localised processes. 
1 Table 3 Median, maximum and minimum values for hydrochemical parameters in the Glen Burn and Nuenna groundwater pathways and

2 respective surface water bodies.

\begin{tabular}{|c|c|c|c|c|c|c|c|c|c|c|c|c|c|c|c|c|}
\hline \multirow{2}{*}{$\begin{array}{l}\text { Monitoring } \\
\text { well }\end{array}$} & \multirow{2}{*}{$\begin{array}{c}\text { GW } \\
\text { Pathway }\end{array}$} & \multirow{2}{*}{$n^{1}$} & & NO3 & NO2 & NH4 & DO & ORP & pH & $\mathrm{Cl}$ & DOC & $\mathrm{HCO} 3$ & SO4 & $\mathrm{Fe} 2+$ & $\delta^{15} \mathbf{N}$ & $\delta^{18} \mathrm{O}$ \\
\hline & & & & $\mathrm{mg} / \mathrm{l}$ & $\mathrm{mg} / \mathrm{l}$ & $\mathrm{mg} / \mathrm{l}$ & $\mathrm{mg} / \mathrm{l}$ & $\mathrm{mV}$ & & $\mathrm{mg} / \mathrm{l}$ & $\mathrm{mg} / \mathrm{l}$ & $\mathrm{mg} / \mathrm{l}$ & $\mathrm{mg} / \mathrm{l}$ & $\mathrm{ug} / \mathrm{l}$ & $\%$ & $\%$ \\
\hline \multirow{3}{*}{ NU1 Deep } & \multirow[t]{3}{*}{ Deep } & \multirow[t]{3}{*}{13} & Med & 23.34 & $<0.1$ & $<0.03$ & 5.11 & 153 & 7.20 & 19.00 & 5.12 & 420 & 8.60 & 45 & 4.49 & 2.55 \\
\hline & & & Max & 25.55 & $<0.1$ & 0.04 & 7.45 & 337 & 7.61 & 20.98 & 6.10 & 488 & 10.50 & 80 & 7.55 & 0.46 \\
\hline & & & Min & 15.98 & $<0.1$ & $<0.03$ & 3.70 & 114 & 7.03 & 14.74 & 1.76 & 285 & 4.72 & $<10$ & 4.46 & 3.02 \\
\hline \multirow{3}{*}{ NU2 Deep } & \multirow[t]{3}{*}{ Deep } & \multirow[t]{3}{*}{15} & Med & 17.54 & $<0.1$ & $<0.03$ & 5.20 & 153 & 7.20 & 13.00 & 5.03 & 430 & 8.00 & 60 & 6.57 & 0.65 \\
\hline & & & Max & 21.08 & $<0.1$ & 0.06 & 7.00 & 335 & 7.80 & 15.00 & 6.04 & 469 & 8.90 & 140 & 5.32 & 2.17 \\
\hline & & & Min & 10.81 & $<0.1$ & $<0.03$ & 2.61 & 71 & 6.98 & 10.51 & 1.58 & 308 & 4.50 & 20 & 5.01 & 3.14 \\
\hline \multirow{3}{*}{$\begin{array}{l}\text { NU1 } \\
\text { Transition }\end{array}$} & \multirow[t]{3}{*}{ Transition } & \multirow[t]{3}{*}{14} & Med & 15.37 & $<0.1$ & $<0.03$ & 4.39 & 155 & 7.10 & 16.00 & 3.19 & 454 & 34.40 & 50 & 5.51 & 3.17 \\
\hline & & & Max & 16.98 & $<0.1$ & 0.29 & 7.30 & 339 & 7.40 & 22.00 & 10.33 & 537 & 71.20 & 340 & 8.20 & 1.08 \\
\hline & & & Min & 5.05 & $<0.1$ & $<0.03$ & 0.00 & 87 & 6.90 & 10.30 & 3.06 & 289 & 5.15 & $<10$ & 5.20 & 3.76 \\
\hline \multirow{3}{*}{$\begin{array}{l}\text { NU2 } \\
\text { Shallow }\end{array}$} & \multirow[t]{3}{*}{ Shallow } & \multirow[t]{3}{*}{19} & Med & 0.21 & $<0.1$ & 0.25 & 0.24 & 99 & 11.07 & 15.10 & 1.41 & 38 & 26.62 & $<10$ & 12.16 & 40.19 \\
\hline & & & Max & 5.70 & 2.66 & 0.67 & 8.43 & 304 & 11.40 & 22.29 & 17.30 & 122 & 32.40 & 20 & 5.66 & 3.14 \\
\hline & & & Min & $<0.1$ & $<0.1$ & $<0.03$ & 0.00 & -212 & 7.57 & 12.27 & 0 & 0 & 22.10 & $<10$ & 5.02 & 3.28 \\
\hline \multirow{3}{*}{ NU2 Subsoil } & \multirow[t]{3}{*}{ Subsoil } & \multirow[t]{3}{*}{14} & Med & 23.83 & 0.12 & $<0.03$ & 5.00 & 143 & 11.15 & 14.65 & 5.15 & 59 & 8.45 & $<10$ & 4.12 & 0.75 \\
\hline & & & Max & 28.50 & 1.27 & 0.07 & 10.00 & 290 & 12.20 & 15.38 & 10.30 & 386 & 12.40 & 60 & 5.34 & 0.09 \\
\hline & & & Min & 18.98 & $<0.1$ & $<0.03$ & 1.95 & -116 & 7.90 & 13.00 & 0 & 0 & 5.92 & $<10$ & 4.25 & 1.50 \\
\hline \multirow{3}{*}{$\begin{array}{l}\text { Nuenna } \\
\text { River }\end{array}$} & & \multirow[t]{3}{*}{14} & Med & 23.74 & $<0.1$ & $<0.03$ & 10.00 & 172 & 7.50 & 13.83 & 5.11 & 399 & 7.53 & $<10$ & 3.29 & -0.67 \\
\hline & & & Max & 26.10 & 0.23 & 0.19 & 15.20 & 334 & 10.30 & 17.00 & 9.41 & 454 & 27.60 & $<10$ & 4.91 & 0.89 \\
\hline & & & Min & 16.37 & $<0.1$ & $<0.03$ & 5.00 & 109 & 7.00 & 11.00 & 4.95 & 55 & 5.23 & $<10$ & 5.00 & 2.99 \\
\hline
\end{tabular}

${ }^{1}$ Selected samples were analysed for DOC, $\mathrm{Fe}^{2+}$ and nitrate isotopes 


\begin{tabular}{|c|c|c|c|c|c|c|c|c|c|c|c|c|c|c|c|c|}
\hline \multirow{2}{*}{$\begin{array}{c}\text { Monitoring } \\
\text { well }\end{array}$} & \multirow{2}{*}{$\begin{array}{c}\text { GW } \\
\text { Pathway }\end{array}$} & \multirow{2}{*}{$n^{1}$} & & \multirow{2}{*}{$\begin{array}{c}\text { NO3 } \\
\mathrm{mg} / \mathrm{l} \\
\end{array}$} & \multirow{2}{*}{$\begin{array}{c}\mathrm{NO2} \\
\mathrm{mg} / \mathrm{l} \\
\end{array}$} & \multirow{2}{*}{\begin{tabular}{|c|}
$\mathrm{NH} 4$ \\
$\mathrm{mg} / \mathrm{l}$ \\
\end{tabular}} & \multirow{2}{*}{$\begin{array}{c}\mathrm{DO} \\
\mathrm{mg} / \mathrm{I} \\
\end{array}$} & \multirow{2}{*}{$\begin{array}{l}\text { ORP } \\
\mathrm{mV} \\
\end{array}$} & \multirow[t]{2}{*}{$\mathrm{pH}$} & \multirow{2}{*}{$\begin{array}{c}\mathrm{Cl} \\
\mathrm{mg} / \mathrm{l} \\
\end{array}$} & \multirow{2}{*}{\begin{tabular}{|c|}
$\mathrm{DOC}$ \\
$\mathrm{mg} / \mathrm{l}$ \\
\end{tabular}} & \multirow{2}{*}{$\begin{array}{l}\mathrm{HCO} 3 \\
\mathrm{mg} / \mathrm{l} \\
\end{array}$} & \multirow{2}{*}{$\begin{array}{c}\mathrm{SO4} \\
\mathrm{mg} / \mathrm{l} \\
\end{array}$} & \multirow{2}{*}{\begin{tabular}{|l} 
Fe2+ \\
ug/I \\
\end{tabular}} & \multirow{2}{*}{\begin{tabular}{|l|}
$\delta^{15} \mathrm{~N}$ \\
$\% o$ \\
\end{tabular}} & \multirow{2}{*}{$\begin{array}{l}\delta^{18} \mathrm{O} \\
\% \text { o } \\
\end{array}$} \\
\hline & & & & & & & & & & & & & & & & \\
\hline \multirow{3}{*}{3.1} & \multirow[b]{3}{*}{ Deep } & \multirow[b]{3}{*}{8} & Med & $<0.1$ & $<0.1$ & $<0.03$ & 0.00 & -163 & 7.50 & 33.09 & 7.35 & 280 & 19.38 & 35 & & \\
\hline & & & Max & 1.04 & 0.29 & 0.10 & 0.38 & -10 & 7.99 & 36.64 & 21.50 & 325 & 21.32 & 90 & & \\
\hline & & & Min & $<0.1$ & $<0.1$ & $<0.03$ & 0.00 & -252 & 7.27 & 30.99 & 6.25 & 228 & 0.55 & $<20$ & & \\
\hline \multirow{3}{*}{6.1} & \multirow[b]{3}{*}{ Deep } & \multirow[b]{3}{*}{10} & Med & $<0.1$ & $<0.1$ & $<0.03$ & 0.00 & -226 & 8.01 & 25.59 & 5.76 & 212 & 36.26 & 60 & 13.08 & 28.13 \\
\hline & & & Max & 2.58 & 0.26 & 0.21 & 0.83 & 26 & 8.13 & 45.27 & 18.10 & 322 & 67.63 & 1240 & 48.89 & 40.39 \\
\hline & & & Min & $<0.1$ & $<0.1$ & $<0.03$ & 0.00 & -254 & 7.38 & 21.58 & 1.20 & 159 & 30.06 & $<20$ & 8.46 & 8.27 \\
\hline \multirow{3}{*}{4.1} & \multirow{3}{*}{$\begin{array}{l}\text { Shallow } \\
\text { and Deep }\end{array}$} & \multirow{3}{*}{9} & Med & 0.5 & $<0.1$ & $<0.03$ & 0.07 & -101 & 6.92 & 17.21 & 8.01 & 244 & 12.14 & 2080 & 44.10 & 28.60 \\
\hline & & & Max & 2.96 & 0.25 & 0.1 & 2.07 & 21 & 7.10 & 39.78 & 18.60 & 306 & 26.60 & 9400 & 51.78 & 30.83 \\
\hline & & & Min & $<0.1$ & $<0.1$ & $<0.03$ & 0.00 & -234 & 5.97 & 10.25 & 2.61 & 81 & 1.88 & $<20$ & 2.72 & 8.49 \\
\hline \multirow{3}{*}{2.2} & \multirow[b]{3}{*}{ Shallow } & \multirow[b]{3}{*}{6} & Med & $<0.1$ & $<0.1$ & $<0.03$ & 0.05 & -184 & 7.99 & 30.79 & 5.75 & 171 & 40.67 & $<20$ & & \\
\hline & & & Max & 3.69 & $<0.1$ & $<0.03$ & 6.66 & 84 & 8.19 & 33.25 & 14.30 & 225 & 47.25 & 1960 & & \\
\hline & & & Min & $<0.1$ & $<0.1$ & $<0.03$ & 0.00 & -312 & 6.82 & 28.40 & 1.49 & 146 & 23.34 & $<20$ & & \\
\hline & & & Med & 1.67 & $<0.1$ & $<0.03$ & 0.24 & -94 & 7.15 & 24.32 & 1.87 & 232 & 19.33 & 170 & & \\
\hline 4.2 & & & Max & 3.69 & $<0.1$ & 0.11 & 6.66 & 84 & 7.29 & 28.73 & & 290 & 32.04 & 1200 & & \\
\hline & Shallow & 3 & Min & $<0.1$ & $<0.1$ & $<0.03$ & 0.05 & -97 & 7.05 & 23.98 & & 212 & 16.86 & 20 & & \\
\hline & & & Med & 7.46 & $<0.1$ & $<0.03$ & 0.65 & -34 & 7.17 & 28.97 & 5.44 & 191 & 32.60 & 20 & 11.89 & 8.83 \\
\hline 6.2 & & 11 & Max & 33.84 & 0.29 & 0.37 & 3.37 & 78 & 7.31 & 33.49 & 16.85 & 208 & 35.87 & 1080 & 13.57 & 11.39 \\
\hline & Shallow & & Min & 2.67 & $<0.1$ & $<0.03$ & 0.14 & -89 & 6.98 & 25.18 & 2.30 & 163 & 27.88 & 20 & 10.18 & 3.02 \\
\hline & & & Med & 9.83 & $<0.1$ & $<0.03$ & 4.15 & 166 & 6.54 & 51.80 & 6.45 & 71 & 20.14 & 20 & 10.35 & 3.34 \\
\hline & & 17 & Max & 23.51 & 0.27 & 0.12 & 8.40 & 243 & 7.13 & 85.42 & 18.90 & 150 & 42.27 & 240 & 11.06 & 7.55 \\
\hline $5.1 \& 5.2$ & Alluvium & & Min & 2.03 & $<0.1$ & $<0.03$ & 2.29 & 15 & 5.73 & 34.93 & 3.77 & 51 & 16.28 & 20 & 9.46 & 2.85 \\
\hline & & & Med & 7.91 & $<0.1$ & 0.04 & 9.12 & & 7.55 & 46.41 & 14.63 & 175 & 34.48 & & 14.05 & 3.51 \\
\hline Glen Burn & & & Max & 17.17 & 0.62 & 1.38 & 14.08 & & 8.46 & 84.00 & 20.22 & 350 & 52.94 & & 23.42 & 8.59 \\
\hline River & & 29 & $\min$ & 3.02 & $<0.1$ & $<0.03$ & 1.50 & & 6.71 & 29.44 & 14.33 & 95 & $<0.2$ & & 11.61 & 1.76 \\
\hline
\end{tabular}




\section{$1 \quad$ 3.1.2 Nitrate Isotopes and nitrate stratification}

2 The artificial tracer single well dilution tests permitted identification of target zones at depth for

3 packer testing to further investigate changes in nitrate fate and transport with depth in the aquifers

4 at a higher resolution. In the Nuenna aquifer the nitrate concentrations are highest in the subsoil and

5 lowest in the shallow groundwater before increasing again in the deep groundwater. Higher

6 resolution depth sampling (Figure 4) showed that nitrate in the deep groundwater does not vary

7 significantly at depth, indicating that the unit is well mixed in the deeper parts of the aquifer and that

8 vertical flow within the monitoring well has negligible influence on the nitrate concentrations.

9 Despite the identification of a hydraulically active fracture at $35.5 \mathrm{mbgl}$ in NU1 Deep and evidence

10 of greater potential for dilution, there was no significant change in nitrate concentrations with depth

11 in the intervals sampled in NU1 Deep. Moreover, relatively little change in $\mathrm{NO}_{3} / \mathrm{Cl}$ ratios or nitrate

12 isotopic signature suggest good mixing with depth in the deeper part of the aquifer and that

13 biogeochemical reactions are not a significant factor influencing nitrate fate once the nitrate enters

14 deeper bedrock.

15 The nitrate isotopic signature of the groundwater and surface water in the Nuenna catchment 16 clusters closely within the ranges for nitrate derived from the nitrification of ammonium fertilisers,

17 soil nitrogen or septic tank waste and manure according to the ranges suggested by Kendall (1998),

18 as shown in Figure 5. The collective groundwater isotopic signatures display an insignificant

19 depletion in $\delta^{15} \mathrm{~N}$ values with declining nitrate concentration, indicating that at catchment scale

20 denitrification is not a significant process. Furthermore, an enrichment ratio of -2.13 between $\delta^{18} \mathrm{O}$

21 and $\delta^{15} \mathrm{~N}$ is inconsistent with denitrification.

22 Nitrate in the transition zone groundwater samples displayed a larger range of variation in $\delta^{15} \mathrm{~N}$ than

23 in the deeper groundwater samples although the range of $\delta^{18} \mathrm{O}$ values is considerably smaller (Table 
1 3). This finding suggests that, prior to nitrification, volatilisation may have caused the enrichment of

2 the $\delta^{15} \mathrm{~N}$ as ammonia. This corroborates the interpretation based on the hydrochemical data which

3 suggest that denitrification has negligible influence on nitrate concentrations in the groundwater at

4 the catchment scale.

5 Although nitrate concentrations are lowest in the shallow groundwater, the nitrate isotopic signature

6 is similar to the nitrate isotope signature in the subsoil groundwater, with one exception, which

7 occurred when the lowest measureable concentration of nitrate was detected $(0.67 \mathrm{mg} / \mathrm{l})$ in the

8 subsoil groundwater; this displayed depleted isotopic values $\left(\delta^{15} \mathrm{~N} 3.29 \%\right.$ and $\delta^{18} \mathrm{O}-0.67 \%$ ).

9 Depleted nitrate isotopic values are indicative of partial nitrification (Kendall \& Aravena 2000;

10 Lehmann et al. 2007) and are consistent with the elevated ammonium concentrations (0.4 mg/l) and

11 nitrite concentrations associated with NU2 Shallow. Although nitrite concentrations were below the

12 limit of detection on this occasion $(0.1 \mathrm{mg} / \mathrm{l})$, when the lowest measurable nitrate was detected, on

13 other occasions nitrite concentrations in the shallow groundwater reached $2.66 \mathrm{mg} / \mathrm{l}$. This

14 concentration in groundwater far exceeds the Environmental Objectives (Groundwater) Regulations

152010 (European Communities 2010) threshold of $0.375 \mathrm{mg} / 1$ and may reflect partial nitrification.

16 Hydrochemical and isotopic findings suggest that it is unlikely that widespread denitrification occurs

17 across the Nuenna but localised partial nitrification may be intermittently occurring in the shallow

18 groundwater with limited impact on catchment surface water quality.

19 The groundwater nitrate isotopic signature in the subsoil falls within a similar range to that in the

20 deep groundwater and resembles the river water's nitrate isotopic signature. Consistent with findings

21 drawn from the hydrochemical analyses, this suggests that nitrification is the dominant process

22 impacting the nitrate in the subsoil and surface water and good hydraulic connectivity exists between

23 the alluvial gravel and the surface water. 


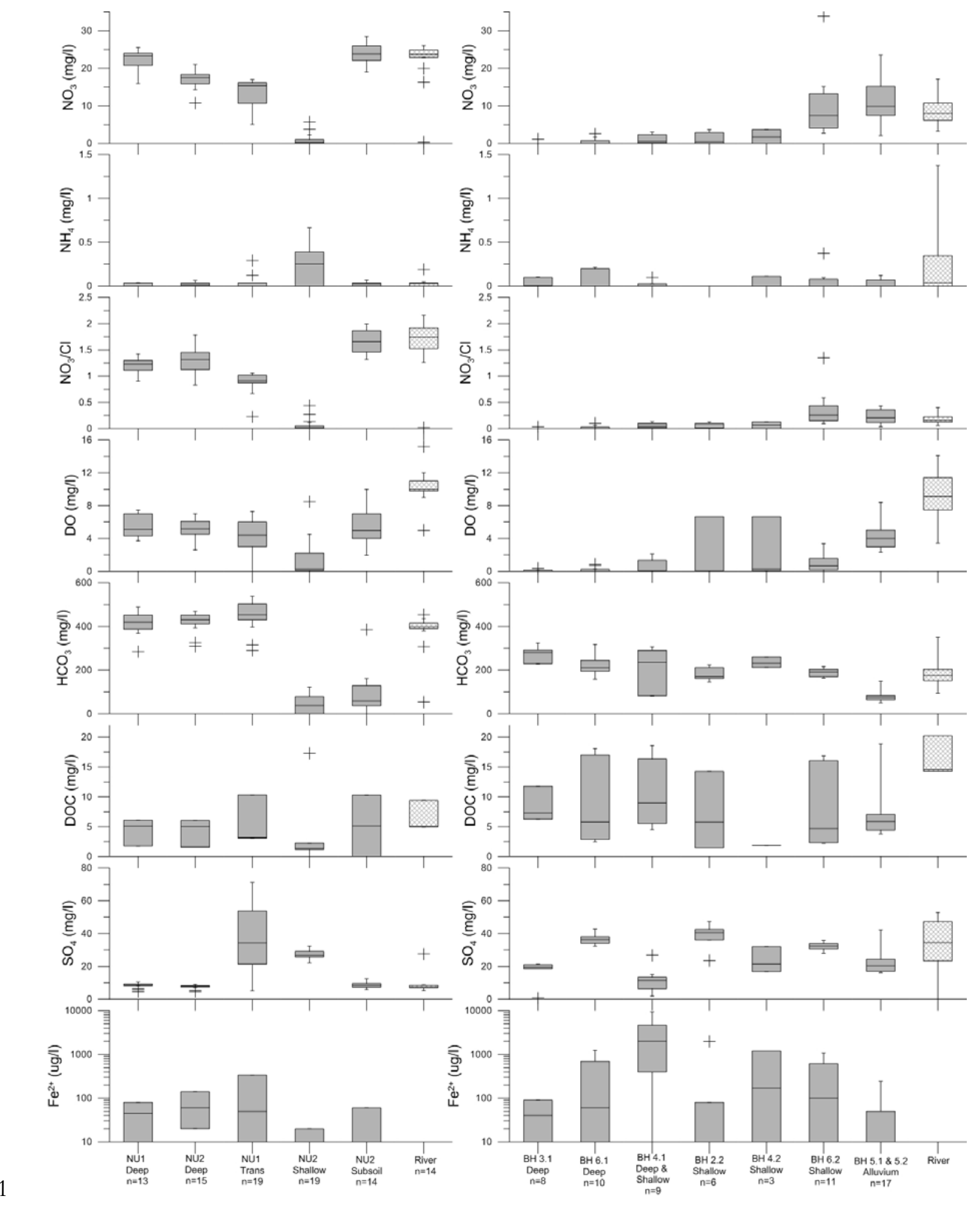

2 Figure $3 \mathrm{Box}$ and whisker plots of $\mathrm{NO}_{3}, \mathrm{NH}_{4}, \mathrm{NO}_{3} / \mathrm{Cl}, \mathrm{DO}, \mathrm{HCO}_{3}, \mathrm{DOC}, \mathrm{SO}_{4}$ and $\mathrm{Fe}^{2+}$ concentrations in 3 groundwater pathways and rivers in the Nuenna and Glen Burn catchments. 


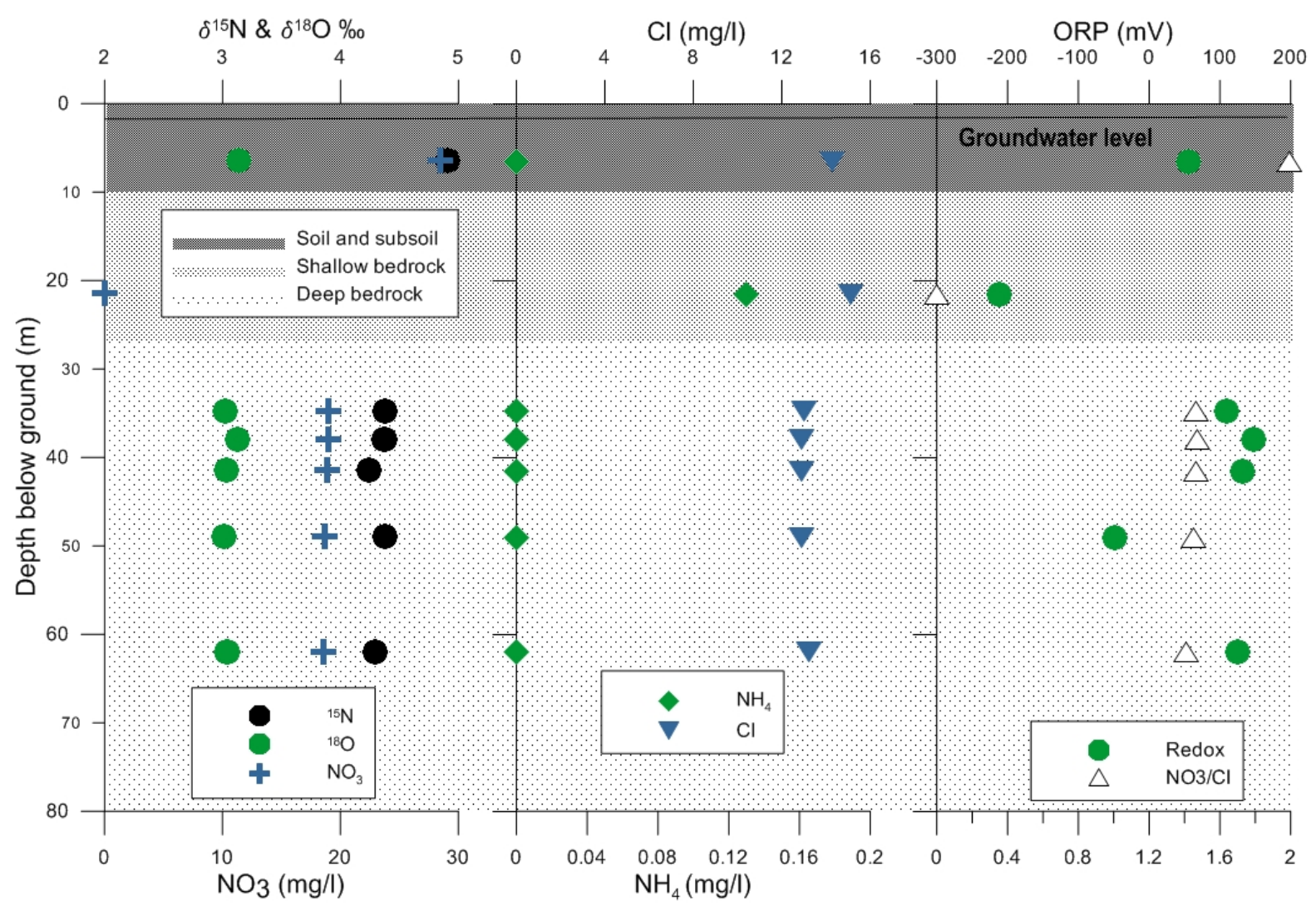

3 Figure 4 Variation of $\mathrm{NO}_{3}, \mathrm{NH}_{4}, \mathrm{Cl}$, ORP concentrations and $\mathrm{NO}_{3}$ isotope $\left(\delta^{15} \mathrm{~N}\right.$ and $\left.\delta^{18} \mathrm{O}\right)$ values with 4 depth in the NU2 cluster, sampled using a packer system and low flow pump.

\subsection{The Glen Burn Catchment}

Uranine (single well) tracer tests carried out in the deep bedrock monitoring well BH 6.1 in the Glen

Burn Catchment identified a hydraulically active fracture zone at $14 \mathrm{mbgl}$ and further active fractures at 16, 26, 31, 38 and $52 \mathrm{mbgl}$ (Nitsche 2014), as shown in Figure 6. Flow velocties were too low and/or uniform in the shallow and deep bedrock at BH 4.1, and in the shallow bedrock monitoring well $\mathrm{BH}$ 6.2, to identify the dominant hydraulically active fracture sets. Overall however, pumping tests indicate that higher hydraulic conductivity occurs in the shallow bedrock compared to the deep

12 (Comte et al. 2012). This, in turn, suggests that the shallower intervals of the bedrock are more 
1 important in terms of groundwater transport, despite the identification of hydraulicaly active

2 fractures at depth; these deeper bedrock fractures appear to have limited connectivity.

\section{$3 \quad 3.2 .1$ Hydrochemistry}

4 Although $\mathrm{N}$ loading intensity in the Glen Burn, is similar to that in the Nuenna catchment, nitrate

5 concentrations in the Glen Burn bedrock groundwater are considerably lower (Figure 3 and Table

6 3), despite comparably thin soil covering (Figure 1). Within the rock more nitrate-rich groundwater

7 was encountered flowing along the shallow groundwater pathway than in the deeper groundwater,

8 although this was found to vary spatially between monitoring well locations across the catchment.

9 Cluster BH6 is located on the south eastern side of a drumlin which is cultivated for tillage, and

10 receives synthetic fertiliser, while $\mathrm{BH} 4$ is located on the eastern side of the same drumlin on the

11 boundary between a tillage field and pasture land and is likely to receive both synthetic and organic

12 nitrogen. The area surrounding the drumlin contains a thin $(<1 \mathrm{~m})$ to absent covering of soil directly

13 over rock. The difference in nitrate concentration in samples collected from shallow monitoring

14 wells at both locations may be due to the difference in landuse practices and to greater synthetic

15 fertiliser application associated with tillage. Thicker (locally derived) till at BH 6.2 (shallow bedrock)

16 (4.90 m) compared to BH 4.2 (deep bedrock) $(0.4 \mathrm{~m})$ can contribute to longer travel times (Fenton

17 et al. 2009). However vertical travel time has been shown to have no correlation with groundwater

18 nitrate concentrations in some Irish catchments (Baily et al. 2011). This is corroborated by higher

19 nitrate concentrations at $\mathrm{BH} 6.2$ compared to $\mathrm{BH} 4.2$ which indicates that preferential flow paths

20 allow relatively rapid transport of contaminants to the shallow groundwater with lower removal

21 capacity or that the higher concentrations occurred as a result of lateral groundwater flow from

22 recharge entering upgradient. 
1 Anaerobic conditions and the presence of electron donors, such as organic carbon, suggest that

2 denitrification occurs in groundwater collected from shallow groundwater monitoring points.

3 Bedrock geochemistry has been shown to have an influence on nutrient mobility in Irish catchments

4 where the presence of pyrite may inhibit nutrient mobility in poorly productive units (Donohue et al.

5 2015). The higher median $\mathrm{Fe}^{2+}$ concentrations in $\mathrm{BH} 4.2$ (shallow bedrock), compared to $\mathrm{BH} 6.2$

6 (shallow bedrock), indicate a greater capacity for autotrophic denitrification in BH 4.2 (Equation 4).

$7 \mathrm{Fe}^{2+}$ concentrations of up to $1200 \mathrm{ug} / 1$ and $1080 \mathrm{ug} / 1$ have been detected in BH 4.2 and BH 6.2

8 respectively, supporting evidence for occasional suitable autotrophic conditions. Pyrite may acts as a

9 potential source of $\mathrm{Fe}^{2+}$ in the denitrification process, which also results in the increase in $\mathrm{SO}_{4}{ }^{2-}$

10 (Equation 4). However this is not consistent with reaction stoichiometry and suggests that other

11 factors are influencing $\mathrm{Fe}^{2+}$ and $\mathrm{SO}_{4}{ }^{2-}$ concentrations in the groundwater. The greywacke bedrock

12 has a high clay content (Comte et al. 2012) which may be a source of $\mathrm{Fe}^{2+}$ as outlined in Equation 5.

13 Other non-pyrite derived Fe sources include detrital silicates and magnetite $\left(\mathrm{Fe}_{3} \mathrm{O}_{4}\right)($ Davidson et al.

14 2003.) Alternative sources of $\mathrm{SO}_{4}$, including atmospheric deposition, fertilisers and the

15 decomposition of organic matter, may contribute to the $\mathrm{SO}_{4}$ concentrations in the groundwater. $\mathrm{SO}_{4}$

16 can be influenced by evapotranspiration, while $\mathrm{Fe}^{2+}$ cannot, however this is unlikely to account for

17 the difference in concentrations as the difference in evapotranspiration is negligible (5\%).

18 Median DOC concentrations of $5.44 \mathrm{mg} / \mathrm{l}$ in $\mathrm{BH} 6.2$ compared to $1.87 \mathrm{mg} / \mathrm{l}$ in $\mathrm{BH} 4.2$ suggest that

19 heterotrophic denitrification is favoured in BH 6.2 over autotrophic denitrification. Consequently,

20 lower nitrate concentrations in $\mathrm{BH} 4.2$ may suggest autotrophic denitrification is more efficient at

21 reducing nitrate. However, as both locations show potential for denitrification, the difference in

22 nitrate is more likely to be a result of variable loadings patterns related to the pressures or the

23 presence of preferential pathways through the overlying till rather than to the type of denitrification. 
1 Nitrate detected in the deep groundwater samples collected from the Glen Burn catchment were

2 consistently less than $2.6 \mathrm{mg} / \mathrm{l}$; this is considerably lower than in the shallow groundwater. Lower

3 transmissivity values have been calculated in the deeper bedrock than in the shallow bedrock (Comte

4 et al. 2012). This may indicate that lower nitrate concentrations in the deep groundwater occur due

5 to reduced flow rates of younger water containing more elevated levels of nitrate flowing to depth,

6 i.e. having a longer travel time. Nonetheless, the presence of detectable levels of nitrate in the deep

7 groundwater points to a recent recharge flow component with the potential to impact groundwater

8 quality. This is consistent with groundwater age dating carried out in the Co. Down greywacke

9 bedrock sampled nearby, which shows that the groundwater contains a measured modern (post

10 1953) component (Cronin 2000). Lower $\mathrm{Cl}$ concentrations in the deeper part of the bedrock,

11 compared to the shallow groundwater pathways, suggest dilution with groundwater containing lower

$12 \mathrm{Cl}$ and nitrate concentrations. However, the contrast in $\mathrm{Cl}$ concentrations at deeper and shallower

13 depths is small (ranging between 3 and $38 \%$ with an average reduction of $14 \%$ ), compared to the

14 contrast in nitrate concentration (ranging between 3 and $100 \%$ with an average reduction of $86 \%$ ),

15 which is frequently below detection limit in the deep groundwater. This highlights that nitrate within

16 the deep groundwater experiences significant additional attenuation through biogeochemical

17 processes; this is consistent with time dependant reactions leading to greater nitrate loss in

18 groundwater with longer residence times (Korom et al. 2012).

19 Lower ORP and DO conditions in the deep bedrock reflect more reducing conditions than in the

20 shallow bedrock (Figure 3 and Table 3). This further implies that conditions in the deep bedrock are

21 more suited to denitrification. DOC concentrations fluctuate spatially in the deep groundwater.

22 Higher median DOC concentrations are evident in $\mathrm{BH} 3.1$ (deep bedrock) compared to $\mathrm{BH} 6.1$

23 (deep bedrock). This also coincides with slightly higher $\mathrm{HCO}_{3}$ concentrations in $\mathrm{BH} 3.1$ compared

24 to $\mathrm{BH}$ 6.1. These findings suggest that conditions in the aquifer up-gradient of BH 3.1 have a greater 
1 capacity for heterotrophic denitrification than at BH 6.1 (nitrate was only detected in $\mathrm{BH} 3.1$ on a

2 single occasion at a concentration of $1.04 \mathrm{mg} / \mathrm{l}$.) Overall hydrochemical evidence therefore points to

3 the significant capacity for denitrification in the deep groundwater.

4 Higher median $\mathrm{Fe}^{2+}$ concentrations in $\mathrm{BH} 6.1$ (deep bedrock) compared to BH 3.1 (deep bedrock)

5 suggest greater autotrophic denitrification capacity in $\mathrm{BH} 6.1$ compared to $\mathrm{BH}$ 3.1. Furthermore,

6 although median $\mathrm{Fe}^{2+}$ concentrations are relatively low, concentrations were higher in the deep

7 groundwater, such as at $\mathrm{BH}$ 6.1, compared to the shallow groundwater at $\mathrm{BH}$ 6.2; which was below

8 the detection limit. Therefore, heterotrophic denitrification is suspected to be more significant in

$9 \mathrm{BH}$ 3.1, while autotrophic denitrification is likely to be more important in $\mathrm{BH}$ 6.1. Despite the

10 evidence for autotrophic denitrification at $\mathrm{BH}$ 6.1, median DOC concentrations at $\mathrm{BH} 6.1$ are also

11 sufficient to promote heterotrophic denitrification. The considerable fluctuation in $\mathrm{Fe}^{2+}$ and DOC

12 concentrations suggest that heterotrophic and autotrophic denitrification may both occur in the

13 vicinity of $\mathrm{BH} 6.1$.

14 The highest $\mathrm{Fe}^{2+}$ concentrations encountered at the Glen Burn site are present in $\mathrm{BH}$ 4.1, which

15 intersects both the shallow and deep bedrock. $\mathrm{Fe}^{2+}$ concentrations are lower in the shallower

16 monitoring well, $\mathrm{BH} 4.2$, and increase with depth. Similar to BH 6.1, low nitrate concentrations and

17 elevated $\mathrm{Fe}^{2+}$ suggest that autotrophic denitrification is occurring. Equation 4 indicates that pyrite

18 mediated denitrification should produce a $\mathrm{SO}_{4}^{2-} / \mathrm{Fe}^{2+}$ molar ratio of $2: 1 . \mathrm{SO}_{4}{ }^{2-}$ is relatively low in

19 both $\mathrm{BH} 4$ monitoring wells and the $\mathrm{SO}_{4}{ }^{2-} / \mathrm{Fe}^{2+}$ molar ratio is less than 2 , indicating that pyrite

20 oxidation is not the dominant source of electron donors for denitrification or there are other

21 processes affecting the $\mathrm{Fe}^{2+}$ and $\mathrm{SO}_{4}{ }^{2-}$ in the groundwater as previously discussed. The presence of

22 elevated DOC concentrations suggests that heterotrophic denitrification may also be playing an

23 important role in nitrate reduction. 
1 Hydrochemical data show that the fate of nitrate in the groundwater sampled from the alluvium

2 adjacent to the Glen Burn River differs from the fate of the nitrate in the competent bedrock

3 groundwater. The alluvium groundwater contains higher median nitrate concentrations than the

4 deep and shallow groundwater. Aerobic conditions in the alluvium are believed to inhibit

5 denitrification, while concentrations of ammonium lie below the limit of detection, suggesting that

6 ammonium undergoes nitrification as a result of the aerobic conditions.

7 Overall, the Glen Burn findings show that the dominant groundwater pathway is the shallow

8 groundwater pathway for delivering nitrate to aquatic receptors. Denitrification is likely to be

9 occurring in the groundwater resulting in lower nitrate concentrations with depth. Water quality data

10 suggest that both autotrophic and heterotrophic denitrification occurs, yet varies spatially across the

11 site according to available electron donors.

\section{$12 \quad 3.2 .2$ Nitrate Isotopes and nitrate stratification}

13 Nitrate isotope signatures observed in surface water samples collected from the Glen Burn River,

14 fall within the ranges for ammonium fertiliser and for manure and septic tank waste (Figure 5); these

15 sources of nitrate are widely encountered upstream of the sampling points (Meredith 2010) and

16 suggests that the nitrate in surface water has undergone less signature-altering attenuation than the

17 nitrate in the groundwater. Consequently, in a catchment such as the Glen Burn, which displays

18 evidence of considerable subsurface biogeochemical alteration, the surface water nitrate signature

19 may better reflect the original sources of nitrate than the groundwater. Moreover, comparison of

20 surface water isotopic ratios with those from groundwater indicates that groundwater contributes

21 relatively little to the river's discharge; this is consistent with the relatively low BFI calculated for the 22 river. 


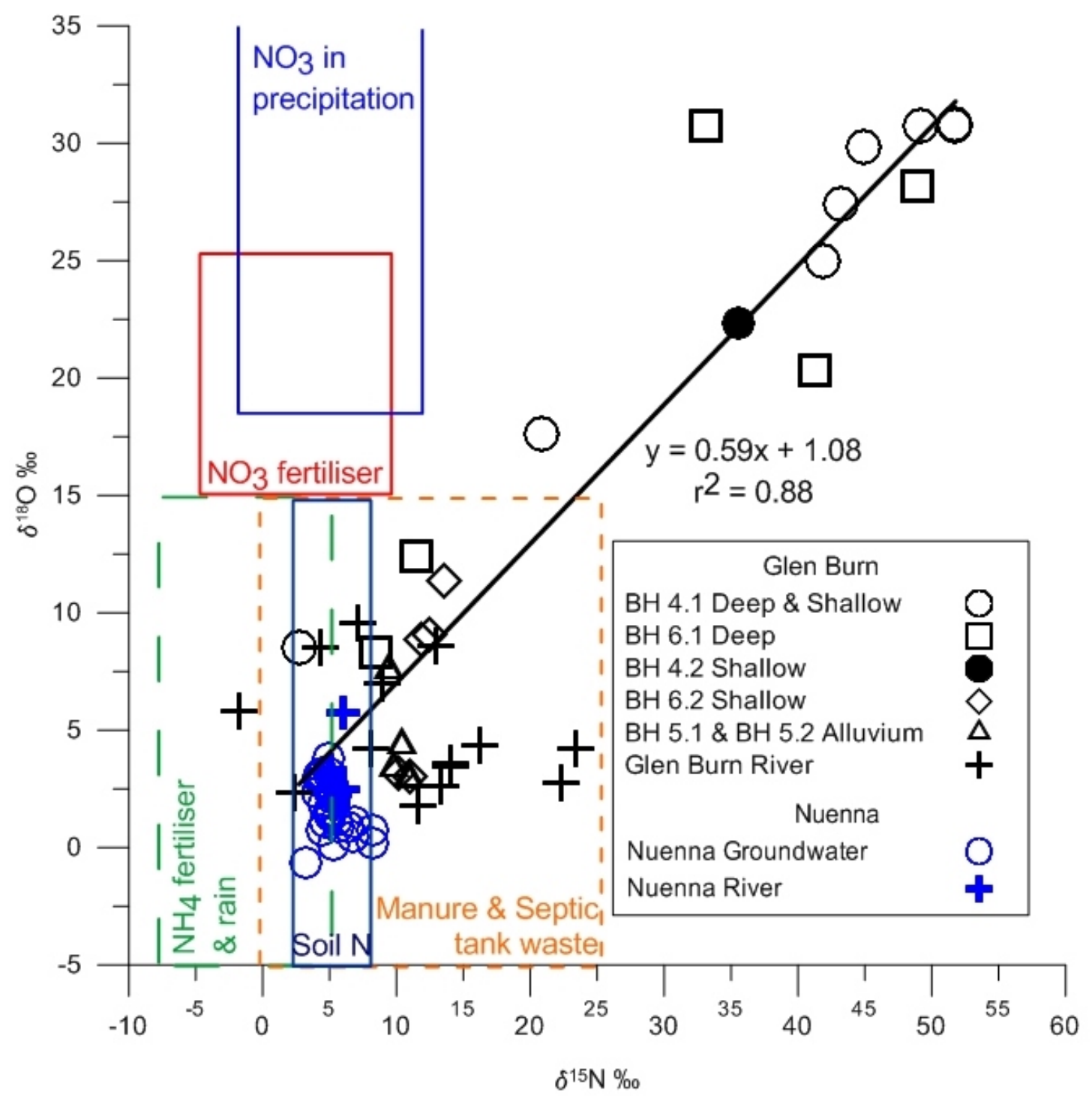

2 Figure $5 \delta^{15} \mathrm{~N}$ and $\delta^{18} \mathrm{O}$ in groundwater and surface water in the Glen Burn catchment. Boxes show the 3 range of $\delta^{15} \mathrm{~N}$ for manure and septic tank waste, $\mathbf{N H}_{4}$ fertiliser and soil $\mathbf{N}$, adapted from Kendall (1998).

4 Overall nitrate concentration decreases with depth in the Glen Burn aquifer, with a considerable

5 reduction between $7 \mathrm{mbgl}$ and $14 \mathrm{mbgl}$ which also corresponds to a reduction in the $\mathrm{NO}_{3} / \mathrm{Cl}$ ratio

6 (Figure 6). The decrease in $\mathrm{NO}_{3} / \mathrm{Cl}$ ratio is suspected to indicate that there is dilution occurring with

7 older water containing lower chloride and nitrate concentrations. However considering the

8 reduction in redox this would suggest that there may be denitrifying conditions. This is supported by

9 the significant enrichment of both the $\delta^{15} \mathrm{~N}$ and $\delta^{18} \mathrm{O}$ which indicates denitrification in the bedrock 
1 groundwater. More enriched nitrate isotopic values in the deep groundwater compared to the

2 shallow groundwater suggest that the rate of nitrate removal through denitrification continues at

3 depth as it infiltrates downwards. This is supported by a general trend across the groundwater

4 samples showing lower groundwater nitrate concentrations yet containing more enriched $\delta^{15} \mathrm{~N}$.

5 Significantly, these values display an enrichment ratio of 1.7 between $\delta^{15} \mathrm{~N}$ and $\delta^{18} \mathrm{O}$ (Figure 5) which

6 is within the enrichment ratio range of between 1.3 and 2.1 attributed to denitrification (Böttcher et

7 al. 1990; Aravena \& Robertson 1998; Fukada et al. 2003).

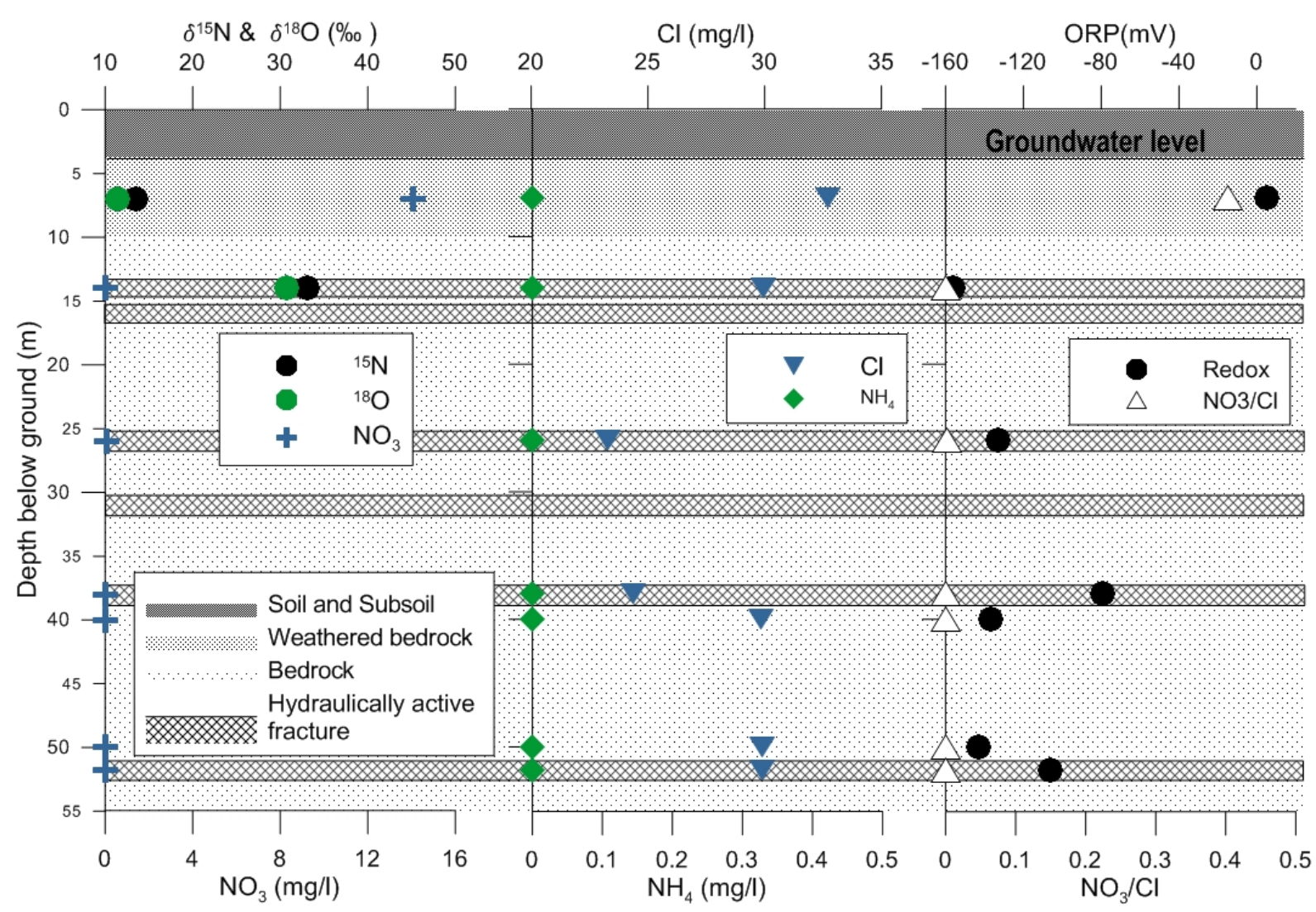

Figure 6 Variation of $\mathrm{NO}_{3}, \mathrm{NH}_{4}$, and ORP concentrations and $\mathrm{NO}_{3}$ isotope $\left(\delta^{15} \mathrm{~N}\right.$ and $\delta^{18} \mathrm{O}$ ) values with depth in BH6 cluster, sampled using a packer system and low flow pump. 
1 Critically, the findings of this study suggest that denitrification processes in the Glen Burn

2 catchment are not restricted to the subsoil as may be the case in the Nuenna catchment, but

3 denitrification is also occurring in the fractured bedrock aquifer. The decrease in nitrate

4 concentration with depth corroborates the findings of the uranine single well tracer tests, which

5 show that the most hydraulically active fractures are in the upper part of the aquifer thus limiting the

6 vertical movement of nitrate into the deeper aquifer. Furthermore the isotopic analysis shows that

7 nitrate which does infiltrate into the bedrock undergoes further denitrification thus preventing more

8 elevated concentrations of nitrate from entering the deeper groundwater body.

11 Groundwater quality in both the Nuenna and Glen Burn catchments is impacted by agricultural

12 contamination. However, the contrasting hydrogeological settings have a significant influence on the

13 dominant biogeochemical processes influencing nitrate fate and transport. The bedrock in both

14 catchments transports groundwater predominantly through fracture flow. However the variation in

15 groundwater discharge via hydraulically active fracture sets with depth and the transmissivity ranges

16 differ considerably in the two catchments investigated. This has considerable influence on the fate

17 and transport of nitrate in the groundwater bodies. Spahr et al. (2010) reported similar findings in a

18 study of 148 sites across various climatic and geological settings in the United States. The study

19 found that lower nitrate concentrations were associated with impermeable soils and impermeable

20 bedrock, whereas catchments with a combination of permeable soils or permeable bedrock were

21 associated with higher nitrate concentrations.

22 The bedrock geochemistry also plays a role in nutrient mobility through the presence of electron

23 donors which are capable of supporting iron-mediated denitrification, such as pyrite, reducing 
1 nitrate mobility. The contrast in water quality between the two catchments is clearly greater than

2 between the monitoring wells within the individual catchments, despite the localised impacts of

3 point sources. This further highlights the significant influence of catchment hydrogeological setting.

4 Nitrification is the dominant biogeochemical process influencing dissolved $\mathrm{N}$ mobility in the

5 Nuenna catchment, where bedrock transmissivity values are higher. Hydrochemical and isotopic

6 data suggest localised anaerobic conditions may occur in a hydrogeological system otherwise

7 dominated by aerobic water that prevents denitrification. Denitrification occurs locally and

8 intermittently in the near surface transition zone, although its influence on a catchment scale is

9 insignificant. The absence of a consistent gradient in hydrochemistry between samples collected

10 from wells in the subsoil and from the deeper bedrock, where lower nitrate was observed in shallow

11 groundwater samples, is consistent with preferential (by-passing) flow mechanisms. Furthermore

12 there is a need for reliable and representative monitoring wells away from point sources in order to

13 determine the target groundwater pathway. In contrast, denitrification is the dominant

14 biogeochemical process affecting aqueous nitrate in the lower transmissivity bedrock of the Glen

15 Burn catchment; the deeper groundwater pathways are more important in higher permeability and

16 karstified bedrock aquifers, such as in the Nuenna catchment.

17 The nitrate isotopic signature in the karstified bedrock aquifer in the Nuenna catchment reflects the

18 original nitrate source more accurately than the nitrate isotopic signature in the lower permeability

19 Glen Burn aquifer, where there is evidence of fractionation due to biogeochemical processes.

20 Consequently, in low permeability bedrock catchments such as the Glen Burn, the groundwater

21 nitrate isotopic signature is likely to be altered from the original source signature and the surface

22 water samples are more likely to represent original nitrate sources in the catchment. 
1 The importance of hydrogeological setting has implications for the groundwater qualtiy monitoring

2 and implementation of contamination mitigation measures in catchments with differing

3 hydrogeological settings. In karstified aquifers nitrate management strategies should focus on the

4 role played by deep groundwater pathways and diffuse nitrogen sources, whereas in catchments

5 underlain by lower permeability aquifers, the deep groundwater will be a less signifincat pathway for

6 nitrate to enter surface water bodies and the focus of such management plans should be on

7 pathways nearer the ground surface. Incorporating these considerations, when developing

8 catchment management plans, can assist in addressing the impact of agricultural practices on the

9 water quality of groundwater bodies and contribute toward achieving the aims of the Water

10 Framework Directive.

\section{Acknowledgements}

13 The authors would like to acknowledge the funding of this research by the Environmental

14 Protection Agency under the Science, Technology, Research and Innovation for the Environment

15 (STRIVE) Pathways Project (2007-WQCD-S1) 2007-2013. Janka Nitsche's research is based on

16 research grant-aided by the Irish Department of Communications, Energy and Natural Resources

17 under the National Geoscience Programme 2007-2013. The views expressed are the authors' own

18 and do not necessarily reflect the views and opinions of the Minister for Communications, Energy

19 and Natural Resources.

20 References

21 Aravena, R., Robertson, W.D. (1998) 'Use of multiple isotope tracers to evaluate denitrification in 22 ground water: study of nitrate from a large septic system plume', Ground water, 36(6), 975$23 \quad 982$. 
1 Archbold, M., Deakin, J., Bruen, M., Desta, M., Flynn, R., Quinn, M.K.-, Gill, L., Maher, P., Misstear, B., Mockler, E., Brien, O., Orr, A., Packham, I., Thompson, J. (2016) Report No . 165 Contaminant Movement and Attenuation along Pathways from the Land Surface to Aquatic Receptors : The PATHWAYS Project.

Baily, A., Rock, L., Watson, C.J., Fenton, O. (2011) 'Spatial and temporal variations in groundwater nitrate at an intensive dairy farm in south-east Ireland: Insights from stable isotope data', Agriculture, Ecosystems \& Environment, 144(1), 308-318.

Böttcher, J., Strebel, O., Voerkelius, S., Schmidt, H.-L. (1990) 'Using isotope fractionation of nitratenitrogen and nitrate-oxygen for evaluation of microbial denitrification in a sandy aquifer', Journal of Hydrology, 114(3-4), 413-424.

British Institute of Standards (2009) BS 6068-6.11:2009, BS ISO 5667-11:2009 Water Quality — Sampling Part 11: Guidance on Sampling of Groundwaters, London.

British Institute of Standards (2003) BS EN ISO 5667-3:2003 BS 6068-6.3:2003 Water Quality — Sampling - Part 3: Guidance on the Preservation and Handling of Water Samples, London.

Burgin, A.J., Hamilton, S.K. (2007) 'Have we overemphasized the role of denitrification in aquiatic ecosystems? A review of nitrate removal pathways', Frontiers in Ecology and the Environment, 5(2), 89-96.

Burkart, M.R., Kolpin, D.W. (1993) 'Hydrological and land-use factors associated with herbicides and nitrate in near-surface aquifers', Journal of Environmental Quality, 22(4), 646-656. 
1 Casciotti, K.L., Sigman, D.M., Galanter Hastings, M., Böhlke, J.K., Hilkert, A. (2002) 'Measurement of the oxygen isotopic composition of nitrate in seawater and freshwater using the denitrifier method', Analytical chemistry, 74(19), 4905-12.

Cawley, A.B.E. (1990) The Hydrological Analysis of a Karst Aquifer System. MSc thesis, Department of Engineering Hydrology, University College Galway.

Comte, J.-C., Cassidy, R., Nitsche, J., Pilatova, K., Ofterdinger, U., Flynn, R. (2012) 'The typology of Irish hard-rock aquifers based on an integrated hydrogeological approach', Hydrogeology Journal, 28(8), 1569-1588.

Cronin, A.A. (2000) Groundwater Flow and Isotope Geochemistry Modelling of the Triassic Sandstone Aqufer, Northern Ireland. PhD thesis, Faculty of Engineering, Queen's University Belfast.

Davidson, E.A., Chorover, J., Dail, D.B. (2003) 'A mechanism of abiotic immobilisation of nitrate in forest ecosystems: the ferrous wheel hypothesis', Global Change Biology, 9, 228-236.

Debernardi, L., De Luca, D.A., Lasagna, M. (2008) 'Correlation between nitrate concentration in groundwater and parameters affecting aquifer intrinsic vulnerability', Environmental Geology, 55(3), 539-558.

Donohue, S., McCarthy, V., Rafferty, P., Orr, A., Flynn, R. (2015) 'Geophysical and hydrogeological characterisation of the impacts of on-site wastewater treatment discharge to groundwater in a poorly productive bedrock aquifer', Science of the Total Environment, 523, 109-119.

Erisman, J.W., Van Grinsven, H., Grizzetti, B., Bouraoui, F., Powlson, D., Sutton, M.A., Bleeker, A., Reis, S. (2011) 'The European nitrogen problem in a global perspective', in Sutton, M.A., 
Howard, C.M., Erisman, J.W., Billen, G., Bleeker, A., Grennfelt, P. and Grizzetti, B., eds., The European Nitrogen Assessment Sources, Effects and Policy Perspectives, University Press: Cambridge, 9-31.

European Communities (2010) Environmental Objectives (Groundwater) Regulations S.I. No 9 of 2010, Dublin, Stationery Office.

Fenton, O., Coxon, C.E., Haria, A.H., Humphreys, J., Johnson, P., Murphy, P., Necpalova, M., Premrov, A., Richards, K.G. (2009) 'Variations in travel time for N loading to groundwaters in four case studies in Ireland: Implications for policy makers and regulators', Tearmann: Irish Journal of Agri-environmental Research, 7, 129-142.

Fukada, T., Hiscock, K.M., Dennis, P.F., Grischek, T. (2003) 'A dual isotope approach to identify denitrification in groundwater at a river-bank infiltration site', Water research, 37(13), 3070_ 8.

Fukada, T., Hiscock, K. M. Dennis, P. F. (2004) 'A dual-isotope approach to the nitrogen hydrochemistry of an urban aquifer’, Applied Geochemistry, 19(5), 709-719.

Giblin, A.E., Tobias, C.R., Song, B., Weston, N., Banta, G.T., Rivera-Monroy, V.H. (2013) 'The Importance of Dissimilatory Nitrate Reduction to Ammonium (DNRA) in the Nitrogen Cycle of Coastal Ecosystems', The Official Magazine of the Oceanography Society, Oceanography, 26(3), 124-131. 
GSI (2016) Data Handling Procedures in the Aquifer Classification Process, available: http://www.gsi.ie/NR/rdonlyres/01C4199F-A257-48A0-A9635CB65A779F6E/0/aquifer_classification_Oct06.pdf [accessed 24 Apr 2016].

Heffernan, J.B., Albertin, A. R., Fork, M.L., Katz, B.G., Cohen, M.J. (2012) 'Denitrification and inference of nitrogen sources in the karstic Floridan Aquifer', Biogeosciences, 9(5), 16711690.

Hiscock, K.M., Iqbal, T., Feast, N. A., Dennis, P.F. (2011) 'Isotope and reactive transport modelling of denitrification in the Lincolnshire Limestone aquifer, eastern England', Quarterly Journal of Engineering Geology and Hydrogeology, 44(1), 93-108.

Hogan, D.J. (2011) Investigating Stream Water Transit Time and Nutrient Uptake under a Range of Flow Conditions Using Conservative and Reactive Tracer Injection Experiments. MSc thesis School of Planning Architecture and Civil Engineering, Queen's University Belfast.

Jahangir, M.M.R., Johnston, P., Khalil, M.I., Richards, K.G. (2012) 'Linking hydrogeochemistry to nitrate abundance in groundwater in agricultural settings in Ireland', Journal of Hydrology 448-449, 212-222.

Jørgensena, P.R., Urup, J., Helstrupb, T., Jensenc, M.B., Eilandd, F., Vinther, F.P. (2004) 'Transport and reduction of nitrate in clayey till underneath forest and arable land', Journal of Contaminant Hydrology, 73, 207-226.

Kendall, C. (1998) 'Tracing nitrogen sources and cycling in catchments', in Kendall, C. and McDonnell, J.J., eds., Isotope Tracers in Catchment Hydrology, Elsevier Science B.V.: Amsterdam, 519-576. 
1 Kendall, C., Aravena, R. (2000) 'Nitrate isotopes in groundwater systems', in Cook, P.G. and Herczeg, A.L., eds., Environmental Tracers in Subsurface Hydrology, Kluwer Academic Publishers: Boston, 261-297.

Kölle, W., Strebel, O., Böttcher, J. (1990) 'Reduced sulphur compounds in sandy aquifers and their interactions with groundwater', in Groundwater Monitoring and Management (Proceedings of the Dresden Symposium March 1987), IAHS Publication no. 173.

Korom, S.F. (1992) 'Natural Denitrification in the Saturated Zone: A review', Water Resources Research, 28(6), 1657-1668.

Korom, S.F., Schuh, W.M., Tesfay, T., Spenser, E.J. (2012) 'Aqufer denitrification and in situ mesocosms: Modeling electron donor contributions and measuring rates', Journal of Hydrology, 432-433(11), 112-126.

Kuenen, J.G. (2008) 'Anammox bacteria: From discovery to application', Nature Reviews/Microbiology, 6, 320-326.

Lehmann, M.F., Sigman, D.M., McCorkle, D.C., Granger, J., Hoffmann, S., Cane, G., Brunelle, B.G. (2007) 'The distribution of nitrate $15 \mathrm{~N} / 14 \mathrm{~N}$ in marine sediments and the impact of benthic nitrogen loss on the isotopic composition of oceanic nitrate', Geochimica et Cosmochimica Acta, 71(22), 5384-5404.

Mayer, B. (2005) 'Assessing sources and transformations of sulphate and nitrate in the hydrosphere using isotope techniques', in Aggarwal, P.K., Gat, J.R. and Froehlich, K.F.O., eds., Isotopes in the Water Cycle: Past, Present and Future of a Developing Science, International Atomic Energy Agency: Dordrecht, The Netherlands, 67-90. 
1 McAleer, E. (2011) The Effect of Land Use on Stream Nitrogen Dynamics in a Large Agricultural Watershed Dominated by Base Flow, MSc thesis, School of Planning, Architecture and Civil Engineering, Queen’s University Belfast.

4 McConvey, P.J. (2012) Water Framework Directive (2000/60/EC) Aquifer Classification Scheme for Northern Ireland, Commissioned Report for Water Management Unit, Environment and Heritage Service, DoE Northern Ireland, Geological Survey of Northern Ireland.

McLay, C.D.A., Dragten, R., Sparling, G., Selvarajah, N. (2001) 'Predicting groundwater nitrate

(1)
concentrations in a region of mixed agricultural land use: a comparison of three approaches', Environmental Pollution, 115(2), 191-204.

McMillan, L.A., Rivett, M.O., Tellam, J.H., Dumble, P., Sharp, H. (2014) 'Influence of vertical flows in wells on groundwater sampling', Journal of Contaminant Hydrology, 169, 50-61.

12 Meredith, S. (2010) Groundwater Vulnerability Mapping - Glen River Catchment, Ards Peninsula, Co. Down, MSc thesis, School of Planning, Architecture and Civil Engineering, Queen's University Belfast.

15 Minet, E., Coxon, C.E., Goodhue, R., Richards, K.G., Kalin, R.M., Meier-Augenstein, W. (2012) 'Evaluating the utility of $15 \mathrm{~N}$ and $18 \mathrm{O}$ isotope abundance analyses to identify nitrate sources: A soil zone study', Water research, 46(12), 3723-3736. Catchment, Co. Kilkenny. 
1 Mulder, A., van de Graaf, A.A., Robertson, L.A., Kuenen, J.G. (1995) 'Anaerobic ammonium oxidation discovered in a denitrifying fluidized bed reactor', FEMS Microbiology Ecology, 16(3), 177-183.

4 Nitsche, J. (2014) Physical characterisation of groundwater flow systems of poorly productive 5 bedrock aquifers in Ireland, $\mathrm{PhD}$ thesis, School of Planning, Architecture and Civil $6 \quad$ Engineering, Queen’s University Belfast.

7 Nolan, B.T. (2001) 'Related nitrogen sources and aquifer susceptibility to nitrate in shallow ground waters of the United States', Ground Water, 39(2), 290-299.

9 O’Brien, R.J., Misstear, B.D., Gill, L.W., Deakin, J.L., Flynn, R. (2013) 'Developing an integrated hydrograph separation and lumped modelling approach to quantifying hydrological pathways in Irish river catchments', Journal of Hydrology, 486, 259-270.

12 Orr, A. (2014) Hydrogeological Influences on the Fate and Transport of Nitrate in Groundwater, $\mathrm{PhD}$ thesis, School of Planning, Architecture and Civil Engineering, Queen's University Belfast.

Ottley, C.J., Davison, W., Edmunds, W.M. (1997) 'Chemical catalysis of nitrate reduction by iron (II)', Geochimica et Cosmochimica Acta, 61(9), 1819-1828. contamination in karst springs using isotopic and chemical indicators', Chemical Geology, 179(1-4), 113-128. 
1 Puckett, L.J., Cowdery, T. K. (2002) 'Transport and fate of nitrate in a glacial outwash aquifer in relation to ground water age, land use practices, and redox processes', Journal of Environmental Quality, 31, 782-796.

Puls, R.W., Paul, C.J. (1997) 'Multi-layer sampling in conventional monitoring wells for improved estimation of vertical contaminant distributions and mass', Journal of Contaminant Hydrology, 25(1-2), 85-111.

Rivett, M.O., Buss, S.R., Morgan, P., Smith, J.W.N., Bemment, C.D. (2008) Nitrate attenuation in groundwater: a review of biogeochemical controlling processes.', Water research, 42(16), 4215-32.

Rivett, M.O., Smith, J.W.N., Buss, S.R., Morgan, P. (2007) 'Nitrate occurrence and attenuation in the major aquifers of England and Wales', Quarterly Journal of Engineering Geology and Hydrogeology, 40(4), 335-352.

Savard, M.M., Somers, G., Smirnoff, A., Paradis, D., Bochove, E. Van, Liao, S. (2010) 'Nitrate isotopes unveil distinct seasonal $\mathrm{N}$-sources and the critical role of crop residues in groundwater contamination', Journal of Hydrology, 381(1-2), 134-141.

Smith, R.L., Howes, B.L., Duff, J.H. (1991) 'Denitrification in nitrate-contaminated groundwater: Occurrence in steep vertical geochemical gradients', Geochimica et Cosmochimica Acta, 55(7), 1815-1825.

Spahr, N.E., Dubrovsky, N.M., Gronberg, J.M., Franke, O.L., Wolock, D.M. (2010) Nitrate Loads and Concentrations in Surface-Water Base Flow and Shallow Groundwater for Selected Basins in the United States, Water Years 1990-2006, U.S. Department of the Interior, U.S. Geological Survey, Virginia. 
1 Stigter, T.Y., Ribeiro, L., Carvalho Dill, A.M.M. (2006) 'Evaluation of an intrinsic and a specific

2 vulnerability assessment method in comparison with groundwater salinisation and nitrate

3 contamination levels in two agricultural regions in the south of Portugal', Hydrogeology

$4 \quad$ Journal, 14, 79-99.

5 Tarre, S., Green, M. (2004) 'High-Rate Nitrification at Low pH in Suspended- and Attached-

6 Biomass Reactors', 70(11), 6481-6487.

7 Tesoriero, A.J., Liebscher, H., Cox, S.E. (2000) 'Mechanism and rate of denitrification in an 8 agricultural watershed: Electron and mass balance along groundwater flow paths', Water $9 \quad$ Resources Research, 36(6), 1545.

10 Thomasson, A.J., Bouma, J., Lieth, H. (1991) Soil and Groundwater Research Report II: Nitrate in Soils EUR 13501, Commission of the European Communities: Luxembourg.

12 Willey, J.M., Sherwood, L.M., Woolverton, C.J. (2011) Prescott's Microbiology, International. ed, 13 McGraw-Hill: New York. 